
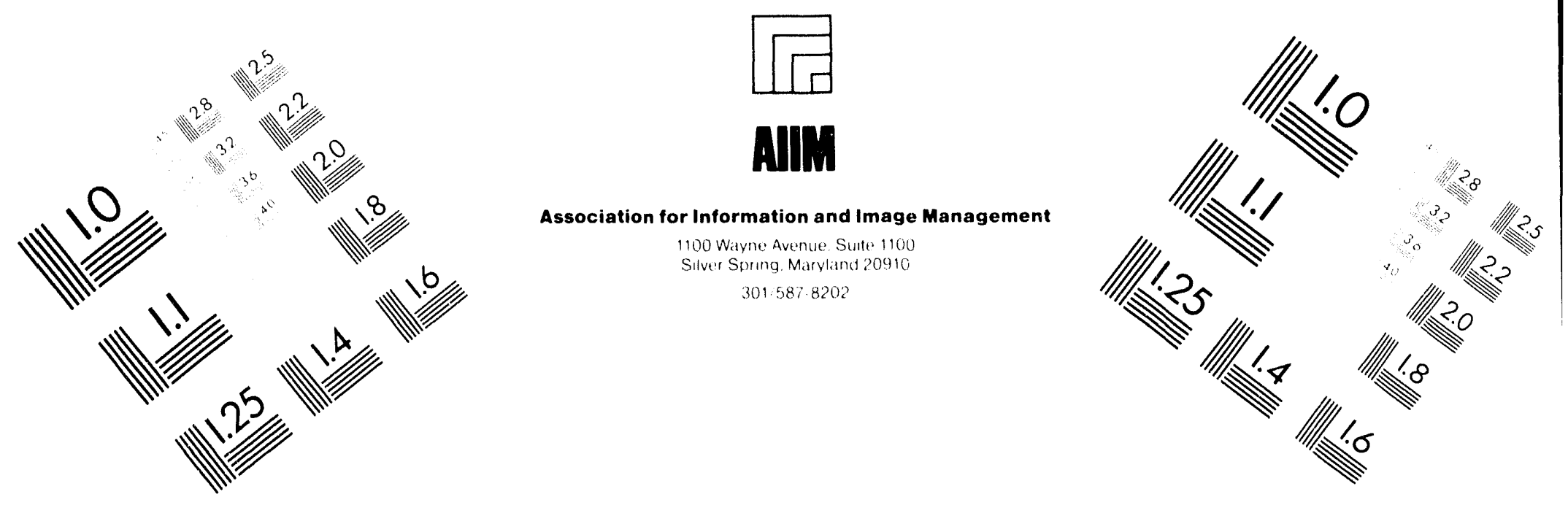

\title{
Centimeter
}

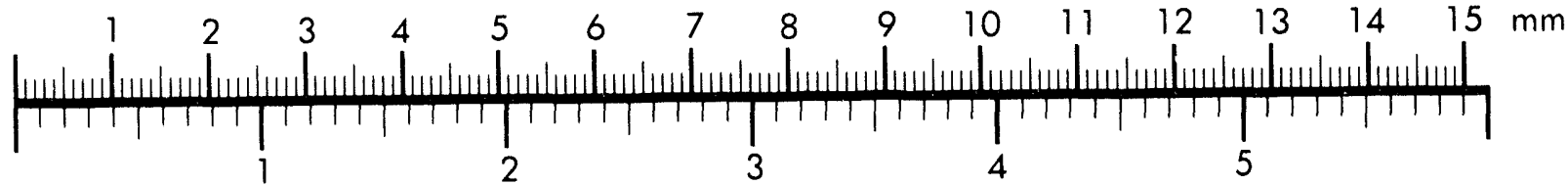
Inches
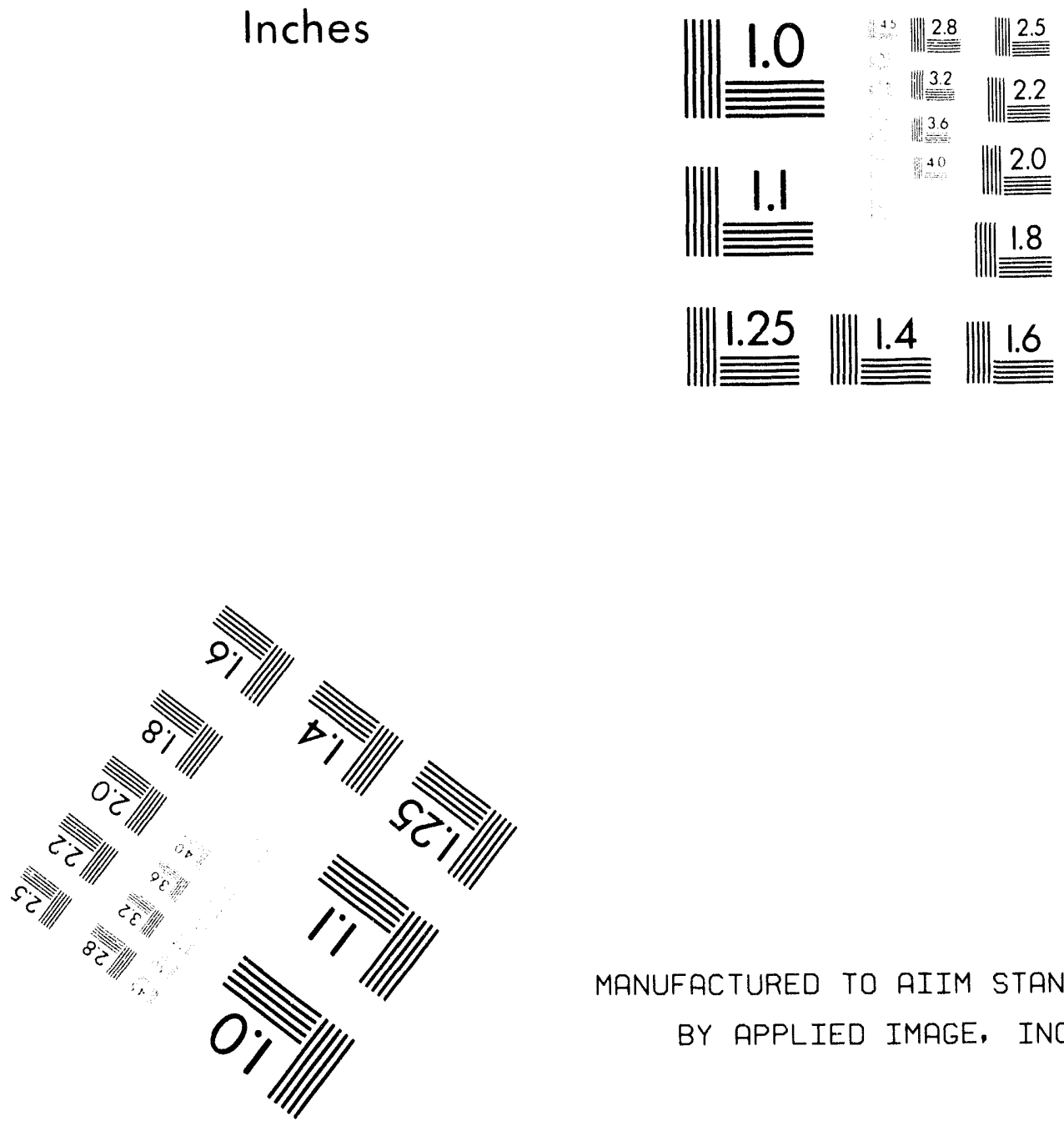

MANUFACTURED TO AIIM STANDARDS BY APPLIED IMAGE, INC.

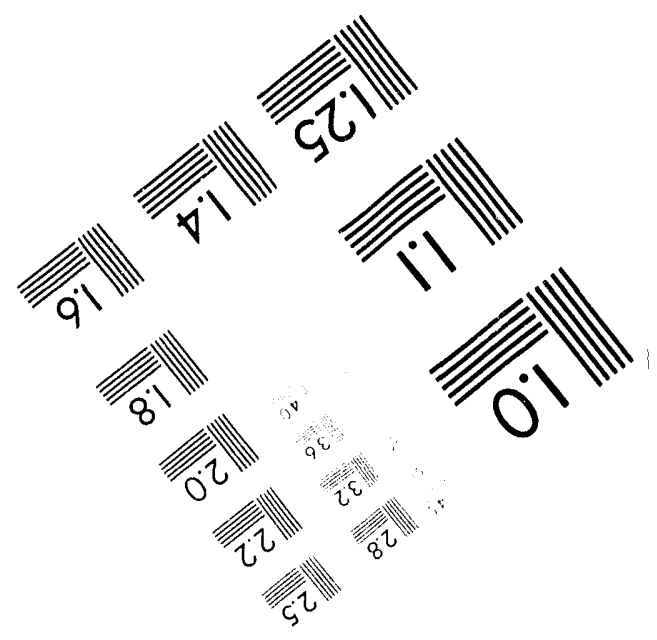



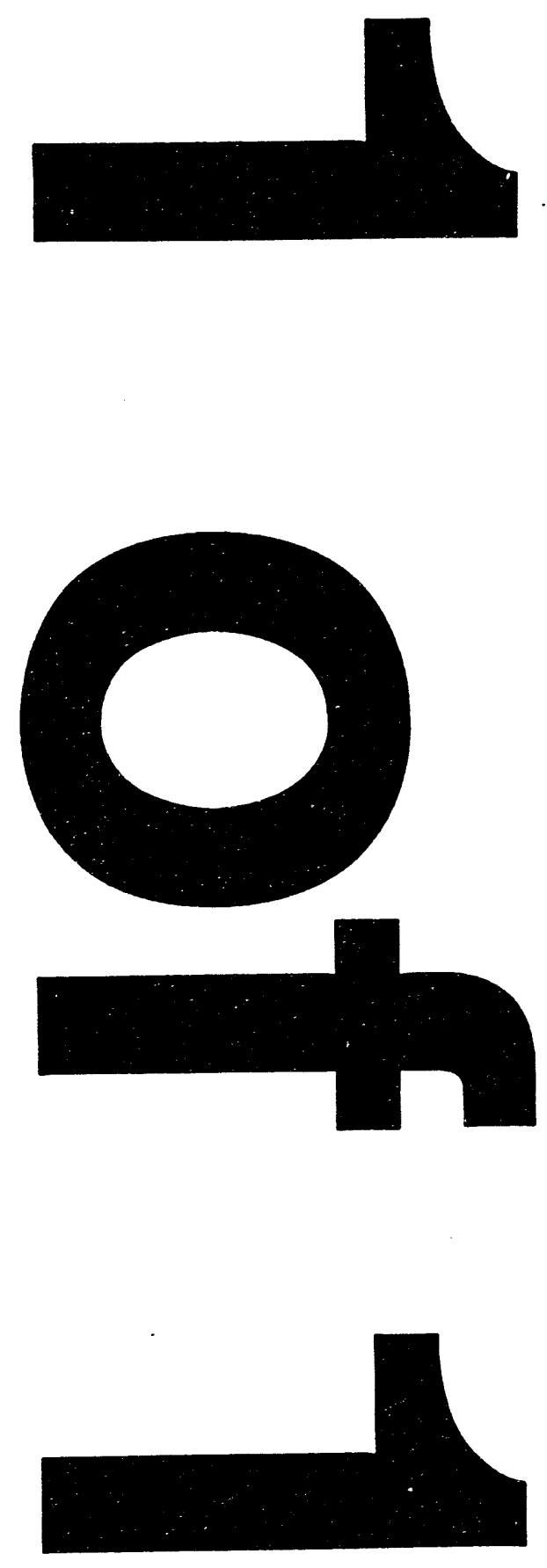
Simple ocean carbon cycle models

\author{
FEC \\ MAY 231.34 \\ OSTI
}

for submission to the proceedings of the

Snowmass Global Change Institute on the Global Carbon Cycle

Ken Caldeira (Global Climate Research Division, Lawrence Livermore National Laboratory, 7000 East Ave, L-262, Livermore CA 94550 USA)

Martin I. Hoffert (Department of Earth System Science, New York University, 26 Stuyvesant Street, New York NY 10003 USA)

Ulrich Siegenthaler (Physics Institute, University of Bern, 3012 Bern, Switzerland) 


\begin{abstract}
Simple ocean carbon cycle models can be used to calculate the rate at which the oceans are likely to absorb $\mathrm{CO}_{2}$ from the atmosphere. For problems involving steadystate ocean circulation, well calibrated ocean models produce results that are very similar to results obtained using general circulation models. Hence, simple ocean carbon cycle models may be appropriate for use in studies in which the time or expense of running large scale general circulation models would be prohibitive. Simple ocean models have the advantage of being based on a small number of explicit assumptions. The simplicity of these ocean models facilitates the understanding of model results.
\end{abstract}

\title{
Introduction
}

Homo sapiens has been significantly perturbing the global carbon cycle for the past several hundred years. We have been taking ancient organic carbon from subterranean environments and modern organic carbon from terrestrial ecosystems, oxidizing it, and injecting the resulting $\mathrm{CO}_{2}$ into the atmosphere. Not all of this $\mathrm{CO}_{2}$ remains in the atmosphere. Some of it is absorbed by the oceans, and some is probably absorbed by terrestrial ecosystems (Siegenthaler and Sarmiento, 1993). A major focus of ocean carbon cycle modelers has been to try to develop models that will lead to more accurate predictions of the rate at which anthropogenic carbon dioxide has been and will be absorbed by the oceans.

The residence time in the atmosphere/biosphere/ocean system of most chemical species of importance to the global carbon cycle gas is greater than $10^{3}$ years (Broecker and Peng, 1982). Hence, on the decadal to century time scale, natural changes in atmospheric $\mathrm{CO}_{2}$ concentration generally reflect a redistribution of carbon among atmosphere, biosphere, and ocean reservoirs, and not a change in the total amount of carbon in those reservoirs taken as a whole. The anthropogenic perturbation to the global carbon cycle can be divided into two classes. The first, the burning of fossil fuels, 
involves adding carbon to Earth's surficial reservoirs. The second, the reduction of biomass associated with land use changes, involves a redistribution of carbon among those reservoirs. With the anthropogenic addition and redistribution of carbon, the atmosphere, biosphere and oceans are perturbed away from their steady-state condition. Barring further perturbation, the atmosphere, ocean, and biosphere will probably tend towards some new steady-state.

Simple ocean carbon cycle models are constructed to reflect the interaction between the atmospheric and oceanic components of the global carbon cycle. These models have been used to predict possible new steady-states of the coupled atmosphere/ocean system, and the transient approach to that steady state. However, accurate prediction of past or future changes on the decadal to century time scale requires a coupled atmosphere/biosphere/ocean carbon cycle model. However, the biospheric component of the Earth's carbon cycle is discussed elsewhere in this volume (ref?), and is outside the scope of this paper.

\section{Box models}

The standard approach to modeling the global carbon cycle and its oceanic component has been the multi-box mass exchange method (Revelle and Suess, 1957; Bolin and Eriksson, 1959; Broecker et al., 1971; Machta, 1973; Hoffert, 1974; Keeling, 1973, 1977; Bacastow and Keeling, 1973, 1977). Transient multi-box formulations are intuitively appealing for finding the time-variation of the mass $\left(\mathrm{N}_{\mathrm{i}}\right)$ of carbon, carbon isotopes, nutrients or other oceanic tracers in each of a number of well-mixed carbon cycle reservoirs in response to a specified source of sink term $\left(S_{i}\right)$.

Box models normally assume first-order transport kinetics in which the outflux from box $\mathrm{i}$ to some adjacen: box $\mathrm{j}$ is $\mathrm{k}_{\mathrm{ij}} \mathrm{N}_{\mathrm{i}}$ leading to reservoir differential equations of the form 


$$
\frac{d N_{i}}{d t}=\sum_{i=1}^{n}\left(\kappa_{j i} N_{j}-\kappa_{i j} N_{i}\right)+S_{i}
$$

where $\mathrm{n}$ is the number of boxes. The exchange coefficients $\kappa_{\mathrm{ij}}$ have inverse time units and are normally calibrated to recover the observed distribution of carbon-isotopes and other tracers among the various ocean reservoirs in steady state $\left(d \mathrm{~N}_{\mathrm{j}} / \mathrm{dt}=0\right)$ ). (Before the availability of simulated three-dimensional internal ocean currents from numerical ocean circulation models, there were no data sets representing advective, diffusive, and convective fields in the global ocean.) In practice, it is often more convenient to work with concentrations rather than masses of tracers. These two forms are mathematically equivalent.

Any of the models presented here (see Table 1) can be used in at least two modes, depending on whether the atmosphcric $\mathrm{CO}_{2}$ concentration is considered part of the model, or whether that concentration is considered an upper boundary condition for the ocean model. In the forward calculations, when we are computing the effect of anthropogenic $\mathrm{CO}_{2}$ releases, the change in atmospheric $\mathrm{CO}_{2}$ mass is computed as the sum of fossil fuel and net biosphere $\mathrm{CO}_{2}$ emissions, less the net $\mathrm{CO}_{2}$ absorption from the oceans. In the inverse calculation, when we are determining what $\mathrm{CO}_{2}$ emissions would consistent with attaining specified atmospheric $\mathrm{CO}_{2}$ concentration targets, the permissible fossil fuel emissions would be the change in atmospheric $\mathrm{CO}_{2}$ mass plus the rate of net $\mathrm{CO}_{2}$ absorption by the oceans less the net emission of $\mathrm{CO}_{2}$ by the biosphere.

The simplicity of box-ocean carbon cycle models is deceptive. As we will discuss here, critical features of the ocean carbon cycle, including chemical buffering by the surface oceans, the subjective choice of how to disaggregate the ocean into subreservoirs (Table 1), the transition from continuous versus discrete formulations, and the calibration of empirical exchange coefficients, are fraught with pitfalls. Some of these are wellunderstood, other uncertainties remain. 


\section{A one-box ocean carbon cycle model}

Before we look at how simple models calculate a response of the global carbon cycle to atmospheric $\mathrm{CO}_{2}$ perturbations, we will look at what controlled the pre-industrial state of ocean chemistry.

In the long-term $\left(>10^{5} \mathrm{yr}\right.$ ) carbon cycle, the atmospheric $\mathrm{CO}_{2}$ concentration is thought to be controlled by relations among geologic $\mathrm{CO}_{2}$ degassing, silicate-rock weathering and atmospheric $\mathrm{CO}_{2}$ concentration (Walker et al, 1981). The chemical weathering of silicate rocks supplies $\mathrm{Ca}^{2+}$ to the oceans. Most of that $\mathrm{Ca}^{2+}$ is eventually deposited as $\mathrm{CaCO}_{3}\left(=\mathrm{CaO} \cdot \mathrm{CO}_{2}\right)$ on the continental shelves or the ocean floor. In this way, each mole of $\mathrm{Ca}^{2+}$ weathered out of silicate rocks generally results in a mole of $\mathrm{CO}_{2}$ sequestered in marine sediments. The silicate-rock weathering rate is thought to be positively correlated with atmospheric $\mathrm{CO}_{2}$ content. This creates a negative feedback loop whereby atmospheric $\mathrm{CO}_{2}$ adjusts such that the $\mathrm{Ca}^{2+}\left(\right.$ and $\mathrm{Mg}^{2+}$ ) flux to the oceans derived from silicate-rock weathering balances the $\mathrm{CO}_{2}$ degassing flux from the mantle and metamorphism. (A study of the long-term fate of anthropogenic $\mathrm{CO}_{2}$ emissions involving these processes in a multi-box ocean model can be found in Walker and Kasting, 1992).

Perhaps the simplest model of the ocean carbon cycle is a one-box model, in which the entire ocean is considered to be a single well-mixed reservoir. Such an approach was taken by Berner et al. (1983) in their model of the long-term ( $\left.>10^{5} \mathrm{yr}\right)$ carbon cycle.

In the natural carbon cycle, unperturbed by human induced $\mathrm{CO}_{2}$ emissions, the primary source of carbon to the oceans and atmosphere comes from volcanoes, midocean-ridges, $\mathrm{CO}_{2}$-rich hot springs, and the weathering of carbonate rocks and sedimentary organic carbon. Most of this carbon is subsequently sequestered in sediments as carbonate rock and organic carbon. In the model of Berner et al (1983), ocean calcium and carbon concentrations adjust to satisfy two conditions: (1) the partial pressure of $\mathrm{CO}_{2}\left(\mathrm{CO}_{2}\right)$ in the surface ocean approaches the value determined by 
considerations involving silicate-rock weathering and $\mathrm{CO}_{2}$ degassing rates; and (2) calcite sedimentation balances sources of calcium and carbon to the ocean.

The ocean is approximately saturated with respect to calcite $\left(\mathrm{CaCO}_{3}\right)$. Berner et al (1983) reasoned that as the saturation state with respect to calcite increases, so would the rate of calcite sedimentation, and this would draw down the oceanic reservoir of calcium and dissolved $\mathrm{CO}_{2}$. They schematically wrote this reaction as:

$$
\mathrm{Ca}^{2+}+2 \mathrm{HCO}_{3}^{-} \rightarrow \mathrm{CaCO}_{3}+\mathrm{CO}_{2}+\mathrm{H}_{2} \mathrm{O} \text {, }
$$

and parameterized the rate of calcite deposition as a function of the degree of disequilibrium of this reaction. This simple one-box ocean carbon-cycle model can give insight into factors controlling ocean chemistry on long time scales. It highlights that the long-term chemistry of the oceans, including factors such as ocean $p H$ and the concentration of total dissolved carbon, is largely determined by the atmospheric $\mathrm{CO}_{2}$ concentration, the rate at which rivers transport dissolved chemicals to the oceans, and the dissolution and/or precipitation of calcite.

A one-box model incorporates the assumption that the ocean can be treated as a well mixed reservoir. However, the ocean exhibits significant inhomogeneity with respect to dissolved concentrations of carbon, carbon isotopes, alkalinity, phosphate, nitrate, oxygen, cadmium, temperature, salinity, and many other tracer fields. A one-box model cannot reproduce the time-dependent structure of the response of the carbon cycle to the anthropogenic $\mathrm{CO}_{2}$ perturbation, because the time scale of the perturbation is short relative to the ocean mixing time scale $(\sim 1000 \mathrm{yr})$.

After several centuries, interactions with ocean sediments become an important factor affecting atmospheric $\mathrm{CO}_{2}$ content (Sundquist, 199x); hence, to obtain relatively precise results for predictions many centuries into the future, ocean and atmosphere models must consider interactions involving marine sediments. However, for most problems relating to the carbon cycle on the decadal to century time scale, the atmosphere, biosphere, and ocean may be considered jointly as a closed system. 


\section{$\therefore$ two-box ocean carbon cycle model}

\section{Ocean carbon pumps}

The concentration of carbon is greater in the deep ocean than in the surface ocean. This is primarily due to two factors: the "biological pump" and the "solubility pump" (Volk and Hoffert, 1985).

The surface ocean provides the primary base of the marine food chain, because phytoplankton can grow only where there is sufficient light. Irradiance in seawater diminishes with depth on a length scale of some tens of meters (Parsons et al., 1984), so below the base of the ocean's surface mixed-layer, there is little photosynthesis. Some of the organic carbon generated in the mixed-layer falls through the base of the mixed-layer and is oxidized into $\mathrm{CO}_{2}$ deeper in the ocean. Thus, biological production at the ocean's surface provides a $\mathrm{CO}_{2}$ source to the deep ocean. This "biological pump" tends to make the deep ocean $\mathrm{CO}_{2}$ rich relative to the surface ocean.

$\mathrm{CO}_{2}$ is more soluble in cold water than in warm water. Cold water is also more dense than warm water of the same salinity. Hence, cold sinking water tends to have a higher total dissolved $\mathrm{CO}_{2}$ concentration than warm buoyant water. This "solubility pump" tends to make the deep ocean $\mathrm{CO}_{2}$ rich relative to the surface ocean.

The biological pump and the solubility pumps tend to produce a gradient in total dissolved $\mathrm{CO}_{2}$, with concentration increasing with depth. In steady-state, the upward and downward fluxes of carbon must balance; the balancing upward flux of carbon is provided by large-scale ocean mixing processes, which tend to return carbon to the surface ocean where the total dissolved carbon concentration is lower. In many simple models (e.g., Oeschger et al., 1975), this large-scale mixing is represented as a diffusive process. Hence, the ocean can be conceptualized as a system in which the biological and solubility pumps establish a surface-to-deep carbon gradient; this gradient is limited by the back diffusion of total dissolved $\mathrm{CO}_{2}$. 


\section{Fundamental two-box ocean model equations}

The simplest model of the ocean that can represent the difference between surface and deep total dissolved inorganic carbon concentrations is a two-box ocean model (Fig. 1). In such a model, typically, the ocean is divided into two well mixed compartments, a surface ocean and a deep ocean, with some mixing flux specified between the two compartments. The equation for the time rate of change of total dissolved inorganic carbon in the surface-box, $\mathrm{C}_{\S}$, can be represented

$$
M_{s} \frac{d C_{s}}{d t}=F_{\text {mix }}\left(C_{d}-C_{s}\right)-F_{\text {bio }}^{C}-F_{\text {sol }}+F_{\text {gasex }} \text {, }
$$

where $M_{S}$ is the mass of the surface ocean $\left(=\sim 3.6 \times 10^{19} \mathrm{~kg}\right.$ for a $100 \mathrm{~m}$ layer $), F_{\text {mix }}$ represents a mass mixing flux between the surface and deep boxes, $C_{d}$ is the concentration of total dissolved inorganic carbon in the deep-ocean box, $\mathrm{F}_{\text {bio }}^{\mathrm{C}}$ is the flux of carbon to the deep ocean produced by the biological pump, $\mathrm{F}_{\text {sol }}$ is the flux of carbon to the deep ocean produced by the solubility pump, and $F_{g a s e x}$ represents the net flux of $\mathrm{CO}_{2}$ into the oceans due to gas exchange with the atmosphere. A corresponding equation for the surface ocean can be written

$$
M_{d} \frac{d C_{d}}{d t}=F_{\text {mix }}\left(C_{s}-C_{d}\right)+F_{\text {bio }}^{C}+F_{\text {sol }}
$$

where $M_{d}$ is the mass of the deep ocean $\left(=\sim 1.3 \times 10^{21} \mathrm{~kg}\right)$.

This simple model can yield some insight into the distribution of carbon in the ocean. For example, in steady-state we can set equation (2) equal to zero, and see that

$$
\mathrm{C}_{\mathrm{d}}-\mathrm{C}_{\mathrm{s}}=\frac{\mathrm{F}_{\mathrm{bio}}^{\mathrm{C}}+\mathrm{F}_{\text {sol }}}{\mathrm{F}_{\text {mix }}}
$$

i.e., the surface-to-deep carbon concentration difference is enhanced by more vigorous biological or solubility pumps, and is diminished by stronger ocean mixing.

\section{A perturbation approach}

If we make the assumptions that (1) the pre-industrial ocean was in steady-state, (2) ocean mixing, and the biological and solubility pumps, are unaffected by the change in atmospheric $\mathrm{CO}_{2}$ in the industrial age, and (3) there was no net $\mathrm{CO}_{2}$ flux into the oceans 
(i.e., $F_{\text {gasex }}=0$ ) in the pre-industrial state, we can develop a perturbation model corresponding to this two-box ocean model.

We can define, two new variables, $\Delta \mathrm{Cd}$ and $\Delta \mathrm{C}_{\mathrm{s}}$, representing the perturbation to their steady-state values, i.e.,

$$
C_{d}=\Delta C d+C_{d, 0}
$$

and

$$
\mathrm{C}_{\mathrm{s}}=\Delta \mathrm{Cs}+\mathrm{C}_{\mathrm{s}, 0} \text {, }
$$

where the subscript 0 indicates a steady-state value. Substituting equations (5) and (6) into equations (3) and (4) with the assumptions stated above, and subtracting the steadystate solution, yields the equations

$$
M_{d} \frac{d \Delta C_{d}}{d t}=F_{\operatorname{mix}}\left(\Delta C_{s}-\Delta C_{d}\right)
$$

and

$$
M_{m} \frac{d \Delta C_{s}}{d t}=F_{\operatorname{mix}}\left(\Delta C_{d}-\Delta C_{s}\right)+F_{g a s e x}
$$

Note that, under these assumptions, the biological and solubility pumps "drop out" of the solution to the perturbation equations. This principal is utilized in many simple ocean models (e.g., Oeschger et al, 1975), as well as general circulation models (e.g., Sarmiento et al, 1992, Majer-Reimer and Hasselmann, 1987), to perform carbon cycle calculations without explicitly modeling ocean biology or the steady-state distribution of carbon in the oceans.

Because one of our primary interests is the absorption by the oceans of $\mathrm{CO}_{2}$ injected into the atmosphere in the course of human activities, we need some way to estimate $F_{\text {gasex }}$, the net flux of $\mathrm{CO}_{2}$ into the oceans due to gas exchange with the atmosphere. $\mathrm{CO}_{2}$ fluxes into the ocean are typically modeled as some gas exchange coefficient ( $\left.\mathrm{k}_{\text {gasex }}\right)$ times the partial pressure of $\mathrm{CO}_{2}$ in the atmosphere $\left(\mathrm{P}_{\mathrm{atm}}\right)$ less the partial pressure of $\mathrm{CO}_{2}$ in the ocean $\left(\mathrm{P}_{\text {ocean }}\right)$ :

$$
F_{\text {gasex }}=k_{\text {gasex }}\left(P_{\text {atm }}-P_{\text {ocean }}\right) \text {. }
$$


In steady-state, in this sort of two-box model, $\mathrm{P}_{\mathrm{atm}}=\mathrm{P}_{\text {ocean }}$ and $\mathrm{F}_{\text {gasex }}=0$. In keeping with our perturbation approach, we can define variables $\Delta \mathrm{P}_{\text {atm }}$ and $\Delta \mathrm{P}_{\text {ocean, }}$ which correspond to the perturbation to the atmospheric and surface ocean partial pressures of $\mathrm{CO}_{2}$ respectively. Furthermore, we can relate $\Delta \mathrm{P}_{\text {ocean }}$ to $\Delta \mathrm{C}_{\mathrm{d}}$, via a factor $\mathrm{B}$ :

$$
\Delta \mathrm{P}_{\text {ocean }}=\mathrm{B} \Delta \mathrm{C}_{\mathrm{S}} \text {, }
$$

i.e., in this simple model we will assume that a perturbation in the surface total dissolved $\mathrm{CO}_{2}$ concentration is linearly related to a change in surface ocean $\mathrm{pCO}_{2}$. Because the partial pressure of mixed-layer $\mathrm{CO}_{2}$ is a non-linear function of total inorganic carbon concentration, this assumption is valid only for small changes in atmospheric $\mathrm{CO}_{2}$ content (see Maier-Reimer and Hasselmann, 1987).

Many simple modes utilize a concept known as the buffer factor $(\zeta)$ to express the fractional change in the partial pressure of $\mathrm{CO}_{2}$ in the mixed-layer $\left(\mathrm{pCO}_{2}\right)$ in relation to a fractional change in mixed-layer total dissolved inorganic carbon $\left(\mathrm{CO}_{2}\right)$ :

$$
\zeta=\frac{\Delta p \mathrm{CO}_{2} / p \mathrm{CO}_{2}}{\Delta\left[\Sigma \mathrm{CO}_{2}\right] /\left[\Sigma \mathrm{CO}_{2}\right]}
$$

The value $B$ in equation (10) is equivalent to $\zeta$ times $\Delta C_{s}$ divided by $P_{\text {ocean. }}$. From table (1), we can calculate that, in this case, the buffer factor $(\zeta=(75.1 / 279) /(48 / 1937))$ takes on a value of $\sim 10.9$ when calculated as a move from the pre-industrial steady-state to the present-day state. On the other hand, when calculated in the opposite direction, going from the present-day state to the pre-industrial state, the buffer factor $(\zeta=$ $(75.1 / 354.1) /(48 / 1985))$ takes on a value of $\sim 8.8$. This little example shows that even within the $\mathrm{CO}_{2}$ changes experienced over the past several hundred years, the assumption of a constant buffer factor can introduce errors on the order of $10 \%$ or more. More advanced parameterizations (e.g., Sarmiento et al., 1992) make the buffer factor depend on the change in surface-ocean concentration of total dissolved inorganic carbon.

If we add an equation for the change of mass of $\mathrm{CO}_{2}$ in the atmosphere, such as

$$
\mathrm{M}_{\mathrm{atm}} \frac{\mathrm{d} \mathrm{P}_{\mathrm{atm}}}{\mathrm{dt}}=F_{\text {human }}-F_{\text {gasex }}
$$


(where $\mathrm{M}_{\mathrm{atm}}$ is the molar mass of the atmosphere, $\mathrm{F}_{\text {human }}$ is the flux of $\mathrm{CO}_{2}$ into the atmosphere brought on by human activity, and net fluxes of $\mathrm{CO}_{2}$ into the terrestrial biosphere are ignored!) this linear system is soluble analytically for the decay of a unit pulse of $\mathrm{CO}_{2}$ into the atmosphere. Unfortunately, the result is an algebraically unwieldy.

From Table 2, we can see that a $2.47 \%$ change in total dissolved carbon concentration corresponds to a $26.9 \%$ change in atmospheric $\mathrm{pCO}_{2}$. This corresponds to a value for $\mathrm{B}$ of $1.6 \mathrm{ppm} /(\mu \mathrm{mol} \mathrm{kg}-1)$. Maier-Reimer and Hasselmann (1987) computed, using an ocean GCM, that the longest time scale for the absorption of $\mathrm{CO}_{2}$ by the oceans was about $360 \mathrm{yr}$. If we take a $360 \mathrm{yr}$ turnover time for the deep ocean as a representative number, then $\mathrm{F}_{\operatorname{mix}}=\mathrm{M}_{\mathrm{d}} / 360 \mathrm{yr}=\sim 3.6 \times 10^{18} \mathrm{~kg} \mathrm{yr}^{-1}$. Net gas exchange between the surface and deep oceans is on the order of $0.06 \mathrm{~mol} \mathrm{C} \mathrm{m-2} \mathrm{yr-1} \mathrm{per} \mathrm{ppm} \mathrm{difference} \mathrm{in} \mathrm{the}$ partial pressure of $\mathrm{CO}_{2}$ in the atmosphere and surface ocean (cf. Maier Reimer and

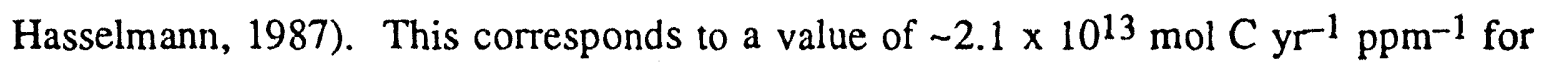
$\mathrm{k}_{\text {gasex }}$. Setting the molar volume of the atmosphere equal to $1.8 \times 10^{20} \mathrm{~mol}$ permits the computation of the response of this two box model to a unit impulse of $\mathrm{CO}_{2}$ (Fig. 2). The results of this calculation, compared with those of Maier-Reimer and Hasselmann (1987), are shown in Figure 1. The two box-model underestimates the uptake of $\mathrm{CO}_{2}$ by the oceans in the first 100 years because the mixing time scales between the surface ocean and ocean thermocline waters is shorter than the mixing-tirne scale between the surface ocean and the deep ocean in its entirety. Nevertheless, this calculation demonstrates that even a model as simple as this two box perturbation model can capture some of the basic features of $\mathrm{CO}_{2}$ absorption by the oceans. The ocean's initially absorb a pulse on a rapid time scale associated with the equilibration of the surface ocean waters with the atmosphere. Then the absorption process is dominated by slower process of transporting carbon from the surface ocean to the deep ocean.

The assumptions that ocean circulation, and the biological and solubility pumps, remain unchanged in a higher $\mathrm{CO}_{2}$ world allowed these pumps to be ignored in this 
perturbation calculation. However, if global warming were to significantly change ocean circulation, these assumption might no longer be valid.

\section{A Simple Biological Carbon Flux Model}

This two box model can be used to demonstrate how the biological pump may be explicitly modeled. The flux of biogenic matter from the surface-to-deep ocean alters the oceanic carbon, nutrient, oxygen and alkalinity fields. In such models, phosphate is typically taken to be the nutrient limiting biological productivity (e.g., Broecker and Peng, 1982), although nitrate (Fasham et al., 1993), iron (Martin, 1991), or zooplankton grazing (Fasham et al, 1993) may also limit productivity in the surface ocean.

In order to calculate the effect of changes in biological export from the mixed-layer might have on the carbon cycle, this export must be linked to the carbon cycle. This is typically done through a concept known as "Redfield ratios" (Redfield et al., 1963; Broecker and Peng, 1982). The proportions of carbon, alkalinity, phosphate, and nitrate in the organic matter transported out of the base of the mixed-layer are approximately constant throughout the world ocean. The ratios of silica ar:d carbonate minerals to the organic conslituents are more highly variable, as upwelling zones tend to be dominated by siliceous diatoms, whereas carbonate secreting organisms tend to dominate in more oligotrophic regions. Redfield ratios express the proportions of elements in the biogenic flux of matter transported out of the base of the mixed-layer.

The ratios of carbon-to-phosphate $\left(\mathrm{R}_{\mathrm{C}: \mathrm{P}}\right)$ and alkalinity-to-phosphate $\left(\mathrm{R}_{\mathrm{Alk}} \mathrm{P}\right)$ in the detrital "rain" out of the mixed-layer has classically been taken to be 132.5 and 38 , respectively. (This assumes that $80 \%$ of the detrital rain is composed of organic matter and that $20 \%$ is composed of calcite and aragonite.) The phosphate and carbon cycles are then linked by assuming

$$
\mathrm{F}_{\text {bio }}^{\mathrm{C}}=\mathrm{R}_{\mathrm{C}: \mathrm{P}} \mathrm{F}_{\text {bio }}^{\mathrm{P}}
$$

Changes in marine, biological productivity would affect the surface alkalinity concentration. Since this will have ail impact on the partial pressure of $\mathrm{CO}_{2}$ in the 
surface waters, and thereby affect the atmospheric $\mathrm{CO}_{2}$ concentration, the alkalinity field must be calculated to properly estimate the distribution of carbon in the ocean and atmo ${ }_{2}$ here. Equations for alkalinity parallel the equations for carbon, except that there is no exchange in the atmosphere, and alkalinity transport in the detrital rain is the product of $\mathrm{R}_{\mathrm{Alk}} \mathrm{P}$ and $\mathrm{F}_{\text {bio }}^{\mathrm{P}}$.

The equations for the time rate of change of the surface phosphate concentration $\left(\mathrm{P}_{\mathrm{S}}\right)$ may be written

$$
M_{s} \frac{d P_{S}}{d t}=F_{\text {mix }}\left(P_{d}-P_{s}\right)-F_{\text {bio }}^{P}
$$

and the deep-ocean phosphate concentration $\left(\mathrm{P}_{\mathrm{d}}\right)$ may be calculated by assuming a constant total ocean phosphate reservoir $\left(\mathrm{P}_{\text {tot }}\right)$.

$$
P_{\text {tot }}=M_{s} P_{s}+M_{d} P_{d}
$$

In the simplest form of such models, surface phosphate concentrations are taken to be constant, and the $\mathrm{F}_{\mathrm{bio}}^{\mathrm{P}}$ is calculated to maintain a constant concentration (e.g., Toggweiler and Sarmiento, 1984). In the next level of complexity, ${ }_{b i o}^{p}$ may be taken to be an increasing function of phosphate concentration. The simplest such statement would be

$$
\mathrm{F}_{\text {bio }}^{\mathrm{P}}=\mathrm{k}_{\text {bio }} \mathrm{P}_{\mathrm{s}} \text {, }
$$

where $\mathrm{k}_{\mathrm{bio}}$ is a constant relating biological export from the mixed-layer to mixed-layer phosphate concentration. More complicated formulation may involve Michaelis-Menton kinetics (e.g., Maier Reimer, 1993) or represent ecosystem structure (Fasham et al, 1993).

With equations (14) to (16), it can be shown that in steady-state, the fraction of nutrients imported into the mixed-layer that gets exported as biological detritus ( $f=$ $\left.\mathrm{F}_{\text {bio }}^{\mathrm{P}} /\left(\mathrm{F}_{\text {mix }} \mathrm{P}_{\mathrm{d}}\right)\right)$ is

$$
\mathrm{f}=\frac{\mathrm{k}_{\text {bio }}}{\mathrm{F}_{\operatorname{mix}}+\mathrm{k}_{\text {bio }}},
$$

In this model, as ocean mixing slows, the difference between surface and deep phosphate concentration gets larger. With slower ocean mixing rates, the residence time for water in the mixed-layer is greater, and, hence, nutrients might be expected to be stripped more 
efficiently from the mixed-layer. Consequently, surface-ocean nutrient utilization may become more efficient at slower ocean mixing rates.

\section{Carbonate Chemistry}

Once we are concerning ourselves with changing biological productivity and alkalinity, a constant buffer factor is no longer an acceptable approximation. Typically, at this point, we would have to consider some carbonate chemistry.

The concentration of total dissolved inorganic carbon $\left(\mathrm{\Sigma CO}_{2}\right)$ is

$$
\left[\Sigma \mathrm{CO}_{2}\right]=\left[\mathrm{CO}_{2}\right]+\left[\mathrm{H}_{2} \mathrm{CO}_{3}\right]+\left[\mathrm{HCO}_{3}^{-}\right]+\left[\mathrm{CO}_{3}^{2-}\right] \text {. }
$$

The concentration of total alkalinity ( $\left.\sum A \mathrm{lk}\right)$ is the sum of the charge concentration of all of the negative ions in the ocean for compounds that can easily change their charge (i.e., the weakly dissociated acids):

$$
[\Sigma \mathrm{Alk}]=\left[\mathrm{HCO}_{3}^{-}\right]+2\left[\mathrm{CO}_{3}^{2-}\right]+\left[\mathrm{B}(\mathrm{OH})_{4}^{-}\right]+[\mathrm{OH}-]+[\mathrm{H}+]+\ldots
$$

Because the oceans are electrically neutral, this quantity is equivalent to the sum of the positive charge of all of the ions in the ocean that cannot easily change their charge:

$$
\left[\sum \mathrm{Alk}\right]=\left[\mathrm{Na}^{+}\right]-\left[\mathrm{Cl}^{-}\right]+2\left[\mathrm{Ca}^{2+}\right]+2\left[\mathrm{Mg}^{2+}\right]-2\left[\mathrm{SO}_{4}^{2-}\right]+\ldots
$$

That part of total alkalinity ( $\mathrm{AAlk}$ ) that whose charge is balanced by inorganic carbon species is known as carbon alkalinity $\left(\mathrm{Alk}_{\mathrm{C}}\right)$. The concentration of carbon alkalinity is equal to the sum of the concentration of negative charge associated with dissolved inorganic carbon species:

$$
\left[\mathrm{Alk}_{\mathrm{C}}\right]=\left[\mathrm{HCO}_{3}^{-}\right]+2\left[\mathrm{CO}_{3}^{2-}\right] .
$$

The speciation of all of the ions that can easily change charge adjusts such that they balance the charge required by the ions that cannot easily change their charge. This coupled with conservation of mass for each element, and the equilibrium constants for each reaction, determines the speciation of the various compounds in the ocean.

The basic reactions involving the dissolution and speciation of carbon in the oceans are (see Stumm and Morgan, 1981).

$$
\mathrm{H}_{2} \mathrm{O}+\mathrm{CO}_{2} \leftrightarrow \mathrm{H}_{2} \mathrm{CO}_{3}
$$




$$
\begin{aligned}
\mathrm{H}_{2} \mathrm{CO}_{3} & \leftrightarrow \mathrm{H}^{+}+\mathrm{HCO}_{3}^{-} \\
\mathrm{HCO}_{3}- & \leftrightarrow \mathrm{H}^{+}+\mathrm{CO}_{3}^{2-} \\
\mathrm{H}_{2} \mathrm{O} & \leftrightarrow \mathrm{H}^{+}+\mathrm{OH}^{-}
\end{aligned}
$$

This simplest form of carbonate chemistry is to considers only dissociation reactions involving $\mathrm{HCO}_{3}-$ and $\mathrm{CO}_{3}^{2-}$, and ignores the relatively minor contribution from $\mathrm{CO}_{2}$ and $\mathrm{H}_{2} \mathrm{CO}_{3}$ (Broecker and Peng, 1982). When dissolved $\mathrm{CO}_{2}$ and $\mathrm{H}_{2} \mathrm{CO}_{3}$ are neglected, the partitioning of dissolved inorganic carbon into carbonate and bicarbonate ions can be solved as a simple linear functions of dissolved carbon and carbon alkalinity concentrations. These relations, with the rate constants as specified in Broecker and Peng (1982) are useful for demonstrating the basic behavior of the response of $\mathrm{CO}_{2}$ partial pressure to changes in temperature, alkalinity, and $\mathrm{\Sigma CO}_{2}$ concentration.

Some basic behaviors common to the Broecker and Peng simplification and more elaborate carbonate chemistry models are:

1. Higher total dissolved inorganic carbon concentration $\rightarrow$

higher $\mathrm{CO}_{2}$ partial pressure.

2 Lower alkalinity concentration $\rightarrow$ higher $\mathrm{CO}_{2}$ partial pressure.

3. Warmer water $\rightarrow$ higher $\mathrm{CO}_{2}$ partial pressure.

Marine biological productivity tends to diminish both the inorganic carbon and alkalinity concentrations of the surface ocean waters. However, the diminution of inorganic carbon concentration has a large effect on the $\mathrm{pCO}_{2}$ in the surface ocean; hence, enhanced biological productivity would tend to diminish the partial pressure of $\mathrm{CO}_{2}$ in the surface ocean.

Improved accuracy can be gained by considering the sum of the concentrations of $\mathrm{CO}_{2}$ and $\mathrm{H}_{2} \mathrm{CO}_{3}$, in addition to the concentrations of $\mathrm{HCO}_{3}^{-}, \mathrm{CO}_{3}{ }^{2-}$. This turns the solution of the chemical speciation problem into a quadratic equation, and considerably improves accuracy of the calculation. However, this solution of the system is . till' 
inaccurate for large $\mathrm{CO}_{2}$ perturbations because it neglects the role of borate in the absorption of $\mathrm{CO}_{2}$ by the oceans.

Boric acid dissociates according to the following schematic reaction.

$$
\mathrm{B}(\mathrm{OH})_{3}+\mathrm{H}_{2} \mathrm{O} \leftrightarrow \mathrm{H}^{+}+\mathrm{B}(\mathrm{OH})_{4}^{-}
$$

The dissolution of $\mathrm{CO}_{2}$ in the oceans primarily occurs by two avenues. The first, which involves reactions (22) and (23) going to the right, with (24) going to the left, is equivalent to

$$
\mathrm{CO}_{2}+\mathrm{CO}_{3}^{2-}+\mathrm{H}_{2} \mathrm{O} \rightarrow 2 \mathrm{HCO}_{3}^{-} .
$$

This results in no change to carbon alkalinity, because now the negative charge on one $\mathrm{CO}_{3}{ }^{2-}$ ion is distributed among two $\mathrm{HCO}_{3}-$ ions. The second main avenue for the $\mathrm{CO}_{2}$ to dissolve in the oceans involves reactions (22) and (23) going to the right, with (26) going to the left; this is equivalent to

$$
\mathrm{CO}_{2}+\mathrm{B}(\mathrm{OH})_{4}^{-} \rightarrow \mathrm{HCO}_{3}^{-}+\mathrm{B}(\mathrm{OH})_{3} .
$$

This net reaction increases carbon alkalinity, at the expense of borate alkalinity, i.e., in this reaction negative charge is transferred from dissolved borate to dissolved carbon. Near present-day atmospheric $\mathrm{CO}_{2}$ concentrations, approximately two-thirds of the dissolving $\mathrm{CO}_{2}$ dissolves by equation (27) and one-third by reaction (28). If reaction $(\mathrm{k}+6)$ is not considered, calculated changes in $\mathrm{CO}_{2}$ partial pressure may be off by $30 \%$.

Many carbon cycle modelers use the calculation methods described in Peng et al. (1987). The algorithm presented in this paper includes the minor contributions from the dissociation of species containing $\mathrm{Si}$ and $\mathrm{P}$, and considers changes in salinity, pressure, and temperature.

One consequence of carbonate buffering of the surface oceans is that it is difficult to measure the direct uptake of carbon by the oceans. The small percentage change in ocean total dissolved inorganic carbon concentration at any location is masked by natural variability. For this reason ocean carbon cycle models calibrated on other tracers have 
been employed to estimate the historical and projected future stable carbon uptake rates by the oceans.

\section{N-box ocean carbon cycle models}

\section{Three box models}

Cold $\mathrm{CO}_{2}$-rich water penetrates to the deep ocean, where as warm $\mathrm{CO}_{2}$-depleted water tends to stay near the surface. This tends to diminish the $\Sigma \mathrm{CO}_{2}$ concentration in the surface ocean. To represent this "solubility pump" (Volk and Hoffert, 1985), at least two surface boxes are necessary (Fig. 3). The solubility pump plays a role in the threebox models of Toggweiler and Sarmiento (1985), Krox and McElroy (1984), and Siegenthaler and Wenk (1984). In these models, there are warm and cold surface boxes, and a deep-water box. Instead of including a term explicitly specifying the strength of the solubility pump, as was done for the two-box model developed above, these models calculate the solubility of $\mathrm{CO}_{2}$ in each of the surface boxes as a function of temperature. The solubility of $\mathrm{CO}_{2}$ in the surface boxes affects the $\mathrm{CO}_{2}$ fluxes between the atmosphere and surface ocean boxes, and, hence, the concentration of $\mathrm{CO}_{2}$ in the surface boxes. In these models, the cold surface box tends to have a greater total dissolved $\mathrm{CO}_{2}$ concentration than the warm surface box. Furthermore, in these models, the cold surface box is specified as being the primary locus of deep-water formation. Hence, the higher solubility of $\mathrm{CO}_{2}$ in the cold surface box tends to increase the total dissolved $\mathrm{CO}_{2}$ concentration in the deep ocean box.

\section{Many-box models}

Most organic carbon that falls out of the mixed-layer is oxidized in the upper km of the ocean, whereas most carbonate carbon dissolves in the bottom $\mathrm{km}$ of the ocean. This consideration suggests the possible division of subsurface waters into an intermediatewater box and a deep-water box (Volk and Liu, 1988; Caldeira and Rampino, 1993). The 
inclusion of an intermediate water box permits four-box models to capture features such as the oxygen concentration minimum, a phosphate maximum, and so on.

The desire to represent individual ocean basins and or water masses has led researchers to add even more boxes into simple ocean models constructed along the lines outlined above. Notable efforts in this area have been made by Broecker and Peng (1987; Fig. 4) and Keir (1988, 1989).

\section{The Box-Diffusion Model}

On decadal to century timescales the infusion of anthropogenic $\mathrm{CO}_{2}$ into the ocean may be primarily due to small scale vertical transport in eddies, and not the large scale ocean circulation. This suggests a pure diffusion approach to a perturbation model: Assume that the anthropogenic diffuses into the ocean

A notable perturbation ocean carbon cycle model is the box-diffusion model (Oeschger et al., 1975; Fig. 5). This model represents the ocean as a vertical column of boxes, with neighboring boxes exchanging water parcels at a specified rate. The governing equations for this model, with a finite number of vertical boxes, can be stated in the form of equation (1). However, in the limit of a large number of boxes, the governing equation for the box-diffusion model becomes

$$
\frac{\mathrm{d} \Delta C}{\mathrm{~d} t}=\frac{\mathrm{d}}{\mathrm{d} z}\left(k \frac{\mathrm{d} \Delta C}{\mathrm{~d} z}\right),
$$

where $\mathrm{z}$ is depth in meters and $\Delta \mathrm{C}$ is generally the perturbation to the carbon concentration. At the bottom boundary there is a zero-flux boundary condition. At the surface boundary the flux of carbon into the ocean is specified much as the net gas flux into the ocean was specified in the one-box model.

The box-diffusion carbon cycle model of Ceschger et al. (1975) was a major step demonstrating this relationship between discrete mutilayer ocean box models and continuous pure diffusion models. When the ocean is modeled by a vertical stack of boxes (or layers) of constant thickness $\Delta z$, the net mass exchange between interior layers 
and their top and bottom neighbors is purely diffusive if the exchange coefficient beiween adjacent layers is a constant. In that case the effective eddy diffusivity is $k=x \Delta z^{2}$, where $K=\kappa_{\mathrm{i}, \mathrm{i}+1}=\kappa_{\mathrm{i}, \mathrm{i}-1}$ (see equation 1$)$.

Maier-Reimer and Hasselmann (1987) produced impulse-response functions for the absorption of a $\mathrm{CO}_{2}$-pulses of various sizes injected into the atmosphere using a perturbation approach with an ocean general circulation model. They found that the model response was similar to that of the box-diffusion model of Siegenthaler and Oeschger (1978). That this simple model has been shown to absorb atmospheric $\mathrm{CO}_{2}$ at rates comparable to a much more complicated three-dimensional ocean general circulation model, indicates that a properly calibrated box-diffusion model can be used in applications in it is important to retain moderate accuracy and use a model that is inexpensive to run. A well calibrated box-diffusion model can produce results that are within the uncertainties inherent in ocean general circulation modeling efforts.

Typically, box-diffusion models are calibrated using ${ }^{14} \mathrm{C}$. There are two basic ways of doing this: one is to try to reproduce the steady-state distribution (or inventory) in the ocean of ${ }^{14} \mathrm{C}$ produced by natural processes in the atmosphere; the other is to try to reproduce, as a function of time, the distribution (or inventory) in the ocean of ${ }^{14} \mathrm{C}$ produced during atmospheric atomic bomb tests. Unfortunately, the diffusion coefficients are not the same for the two different calibration methods. Box-diffusion models calibrated using natural ${ }^{14} \mathrm{C}$ absorb $\mathrm{CO}_{2}$ more slowly than box-diffusion models calibrated using bomb ${ }^{14} \mathrm{C}$. Natural ${ }^{14} \mathrm{C}$ has been penetrating into the oceans for as long as there have been oceans, whereas bomb ${ }^{14} \mathrm{C}$ has been penetrating into the oceans only for several decades. Hence, it is thought that natural ${ }^{14} \mathrm{C}$ calibrations may represent a mean ocean-mixing rate on long time scales; whereas bomb ${ }^{14} \mathrm{C}$ calibrations may represent the mean ocean-mixing rate in the upper several hundred meters of the ocean, where most of the bomb ${ }^{14} \mathrm{C}$ resides. 
General circulation models transport carbon vertically in three (and sometimes four) different ways (Fig. 6). The first way is by advective transport of water masses computed using some form of the Navier-Stokes equations. The second way is by a parameterization of convective overturning. Typically, in ocean general models, if a more dense water mass were to sit in a grid cell above a less dense water mass in the grid cell below, the water in the two grid cells is mixed. This tends to transport the anthropogenic carbon perturbation deeper into the ocean. The third way ocean GCMs transport carbon to the deep ocean is by parameterized sub-grid-scale diffusion between neighboring grid cells. This is modeled as some transfer coefficient times the difference in concentration between the neighboring cells, much as the transfer in neighboring layers is modeled in a box-diffusion model. (The fourth method of carbon transport, included in some ocean GCMs, is the biological transport of carbon. See Maier-Reimer, 1993, and Sarmiento et al, 1993.)

Of these methods of carbon transport, only one (advective transport) is calculated from first principals. All of the other methods of carbon transport are computed using quasi-empirical parameterizations. Hence, it is not terribly surprising that a highly parameterized model such as the box-diffusion model can so closely mimic the $\mathrm{CO}_{2}$ uptake behavior of oceanic general circulation models.

\section{The Outcrop Diffusion Model}

There is considerable vertical density stratification in the ocean. In the ocean, warm water tends to sit above denser, cooler, water. Similarly, less saline water tends to sit above denser, more saline, water. But, largely because of the equator-to-pole surface temperature gradient, there is a surface ocean density gradient. Surface waters are less dense in equatorial regions and more dense near the poles. The ocean's dense deep and bottom waters tend to form in the densest polar regions. 
Vertical eddies are damped by vertical density stratification, because buoyancy forces tend to counteract the movement a parcel of water into waters of a different density. In contrast, these forces do little to damp eddies that evolve along surfaces of constant density. Because mixing across surfaces of constant density (diapycnal mixing) is damped, mixing along surfaces of constant density (isopycnal mixing) tends to be much greater. Eddy transport processes in the ocean can be modeled simply as a macroscopic diffusion process, with an effective diffusion coefficient orders of magnitude greater than the value for pure molecular diffusion. Typical isopycnal eddy-diffusion coefficients may be $10^{6}$ times larger than diapycnal eddy-diffusion coefficients. This suggests that it is about as easy for a tracer to diffuse $1000 \mathrm{~km}$ along a nearly horizontal isopycnal surface as it would for the tracer to diffuse $1 \mathrm{~m}$ in the nearly vertical diapycnal direction.

Because the surface ocean is more dense at the poles than in tropical regions, isopycnal surfaces at depth in the tropics tend to outcrop at the poles. Hence, $\mathrm{CO}_{2}$ absorbed by the surface ocean in polar regions may be efficiently transported to deeper, more equatorial waters, along surfaces of constant density.

The box-diffusion model effectively has an isopycnal eddy-diffusion coefficient equal to zero, as water at depth is never exposed to the surface. Siegenthaler (1983) bounded the isopycnal mixing problem by studying what would happen in the limiting case with infinitely rapid isopycnal mixing (and a finite diapycnal eddy-diffusion coefficient). (A one-box model calculates the limiting case with infinite isopycnal and diapycnal eddydiffusion coefficients. Hence, a one-box model, with properly calibrated gas exchange coefficients, calculates the maximum, gas-exchange limited, rate of $\mathrm{CO}_{2}$ absorption by the oceans.)

Siegenthaler (1983) constructed the "outcrop-diffusion" model in which all deeper layers of the ocean were taken to be in direct contact with the atmosphere (Fig. 7). Transport to these deeper layers through the outcrop regions was limited by gasexchange; additional carbon was transported to these deeper layers via diffusion 
processes as in the box-diffusion model. Even when the vertical exchange coefficients in these two models were tuned to produce the steady-state natural ${ }^{14} \mathrm{C}$ profile, it was found that the two models produce significantly different results when calculating the rate of absorption of anthropogenic $\mathrm{CO}_{2}$ by the oceans (Fig. 8). As might be expected, the outcrop-diffusion model absorbs $\mathrm{CO}_{2}$ more readily than the hox-diffusion model; and probably absorbs $\mathrm{CO}_{2}$ faster than the real ocean.

\section{The Upwelling-Diffusion model}

Vertical globally averaged concentration profiles for ocean tracers such as carbon, nitrate, phosphate and oxygen show extrema in the first kilometer or so of the deep ocean. Such extrema at intermediate depths cannot be calculated in a one-dimensional pure diffusion model, as pure-diffusion models tend towards constant or linear profiles. This is because the real ocean not nly diffuses, but on the mean there is a large scale overturning of the oceans.

Deep-water forms in relatively limited areas in the polar regions, and, in the mean, water tends to upwell outside of the polar regions. (In fact, much of this upwelling is localized in certain coastal and equatorial regions, but this geographic variability cannot be captured in a one-dimensional ocean carbon cycle model.) This fact suggests the construction of a model in which polar water is injected in the base of a one-dimensional column representing the non-polar regions of the global ocean (Fig. 9). This model is very similar to the box-diffusion model, except that, in addition to diffusing, tracers are advected towards the ocean surface. The governing equation for distribution of tracers in this model can be represented (Munk, 1966)

$$
\frac{\mathrm{d} c}{\mathrm{~d} t}=\frac{\mathrm{d}}{\mathrm{d} z}\left(k \frac{\mathrm{d} c}{\mathrm{~d} z}\right)+w \frac{\mathrm{d} c}{\mathrm{~d} z} .
$$

Calibration of this model using nutrient and other tracer fields suggests an upwelling velocity $(w)$ of $4 \mathrm{~m} \mathrm{yr}^{-1}$ and a diffusion coefficient $(k)$ on the order of $2000 \mathrm{~m}^{2} \mathrm{yr}^{-1}$ (Hoffert et al., 1981). Other symbols are as in the box-diffusion model. The bottom 
boundary condition of this model reflects the composition of newly formed deep water. With the appropriate choice of the composition of newly formed deep water, this model reproduces observed tracer fields reasonably well (e.g., Volk, 1984; Khesghi et al., 1991). This type of model can be calibrated with a constant value for the eddy-diffusion coefficent $(k)$ to do a reasonably good job reproducing both the bomb and natural ${ }^{14} \mathrm{C}$ profiles (Jain et al., 1993), and was used to compute the thermal inertia of the oceans for the 1990 IPCC report. Perhaps, the two greatest objections that can be made to this model are: (1) there is no unique and obvious way to determine the composition of newly formed deep water, and (2) not all newly formed deep water is bottom water; some newly formed deep water leaves the deep-water forming regions at intermediate depth.

A form of upwelling-diffusion model, known as the HILDA model, has been developed by Shaffer (1989) and Siegenthaler and Joos (1992). This model appends two polar water boxes to the classical upwelling diffusion model. In this model, the deeplayers exchange water with the polar deep-water box, so that polar-water effectively enters the ocean at all depths. Furthermore, this feature also mimics some of the properties of isopycnal mixing. When calibrated using a diffusion coefficient that decreases with depth, this model is able to reproduce the vertical profiles of both bomb and natural ${ }^{14} \mathrm{C}$ (Siegenthaler and Joos, 1992).

\section{Convolution models}

The ocean models discussed above all explicitly consider some kind of ocean buffer factor and explicitly calculate the change in concentrations of various chemical species. However, there is another type of model that is based on parameterized results of general circulation models (Maier-Reimer, 1987; Harvey, 1989; Wigley, 1991). Maier-Reimer (1987) produced exponential curve fits to the change in atmospheric $\mathrm{CO}_{2}$ concentration as a function of time for a variety of $\mathrm{CO}_{2}$-emission pulse sizes using a perturbation approach with an ocean general circulation model. In the appendix to this paper, for a 
variety of emission scenarios, Maier-Reimer compared the full model results with results of a convolution integral calculation.

In a convolution-integral calculation of the ocean carbon cycle, the $\mathrm{CO}_{2}$ concentration in the atmosphere above the pre-industrial concentration $(\Delta C)$, given some $\mathrm{CO}_{2}$ source flux $(E(t))$, is calculated by computing the integral:

$$
\Delta M(t)=\int_{0}^{t} E(u) G(t-u) \mathrm{d} u=\int_{0}^{t} E(t-u) G(u) \mathrm{d} u,
$$

where 0 represents the time at some initial condition when $\Delta M=0$, and $G(t)$ represents the response of the system to a unit impulse of $\mathrm{CO}_{2}$. The impulse-response function, $G(t)$, is "defined as the $\mathrm{CO}_{2}$ signal observed in the atmosphere for a $\delta$-function atmospheric input at time $t=0$ (or equivalently a unit step-function change in the initial atmospheric $\mathrm{CO}_{2}$ concentration)" (Maier-Reimer and Hasselmann, 1987).

In general, convolution integrals produce accurate results only for nearly linear systems. This modeling approach may be useful for small perturbations in which the linearizing assumption of a constant buffer factor. All of the impulse-response functions calculated by Maier-Reimer and Hasselmann represent injections or $\mathrm{CO}_{2}$ into a $265 \mathrm{ppm}$ $\mathrm{CO}_{2}$ atmosphere. Because the response to a $\mathrm{CO}_{2}$ impulse is a function of the initial condition, no convolution of impulses into a 265 ppm atmosphere will appropriaiely reflect the behavior of pulse injected into an atmospheric $\mathrm{CO}_{2}$ content that differs significantly from that value. However, Harvey (1989) and Wigley (1991) have modified the pure impulse-response function calculation to mimic the effects of a changing buffer factor in a way that produces reasonable results for some common $\mathrm{CO}_{2}$ scenarios.

\section{Offline Ocean General Circulation Tracer Models}

One type of model that begins to stretch the notion of a simple ocean carbon cycle model is the offline ocean GCM tracer model (e.g., Maier-Reimer, 1993; Eliason, pers. comm.). First, an ocean GCM is run to a quasi-steady state, and then and the advective, 
diffusive and convective fields (and sea-ice and any other fields that may affect gas exchange or tracer transport) computed by the ocean GCM are stored in a data base. Then a model is run that computes gas exchange fluxes, and moves tracers around in the ocean, using the transport fields from the ocean GCM. In this way ocean GCM tracer results are obtained at a fraction of the expense needed to run the full ocean GCM in a dynamic mode. The primary limitation of this approach is that it cannot be used in scenarios in which changes in atmospheric $\mathrm{CO}_{2}$ affect climate, which in turn affects ocean circulation and, hence, the rate at which the ocean absorbs $\mathrm{CO}_{2}$ from the atmosphere.

\section{Conclusions and discussions}

Why would someone want to use a simple ocean carbon cycle model when complex three-dimensional ocean carbon cycle models such as that of Maier-Reimer (1993) or Sarmiento et al (1992) are available? Simple ocean carbon cycle models, relative to ocean GCMs, are easy to develop, constrain, and test, execute rapidly, and produce understandable output. It is not clear that the added complexity of an ocean GCM produces a better estimate of the rate of $\mathrm{CO}_{2}$-aborption by the oceans than a wellcalibrated simple ocean carbon cycle model. Complex scenarios involving the dynamic coupling of the atmosphere and ocean may need to be simulated using ocean GCMs.

It would be more satisfying if the parameterization in simple ocean models were based on physical principals, instead of calibration to tracer fields. One of the reasons we have some faith in simple ocean carbon cycle models is that their results are generally consistent with ocean GCM results. Ocean GCMs have the satisfying property of being based, in part, on the fundamental physics of fluid motion, but these models too contain quasi-empirical parameterizations of convection and sut-grid-scale eddy-diffusive processes (Schlesinger and Jiang, 1990). Simple ocean carbon cycle models can be constructed to closely mimic the $\mathrm{CO}_{2}$ uptake behavior of general circulation models (e.g., 
Caldeira and Kasting, 1993), and these models can be used in contexts in which the time and expense associated with general circulation models would be prohibitive.

In a model comparison study, Siegenthaler and Sarmiento (1993) showed that schematic ocean models of the type discussed here predict similar present-day carbon uptake rates to models using the current distributions of three-dimensional ocean circulation models when calibrated to recover the global mean penetration depth of bomb radiocarbon measured by the Geochemical Ocean Sections (GEOSECS) Program. Both simple and more complicated ocean carbon cycle models alike predict recent (1980-1989) oceanic carbon uptake rates in the range $2.0 \pm 0.6 \mathrm{Gt} \mathrm{C} \mathrm{yr-1,} \mathrm{when} \mathrm{calibrated} \mathrm{to} \mathrm{the}$ (roughly 1974) global mean bomb-14C penetration depth measured by GEOSECS (Geochemical Ocean Sections Program) of $\sim 354 \mathrm{~m}$.

Interestingly, balances of the global carbon cycle budget based on ocean model estimated uptake rates have led to increased emphasis on the terrestrial carbon cycle. Current ocean models suggest the oceans absorbed $\sim 140 \mathrm{Gt} \mathrm{C}$ since pre-industrial times in addition to the $\sim 160 \mathrm{GtC}$ that has remained in the atmosphere (Sundquist, 1993). The sum of atmospheric and oceanic "sinks" from 1750 to 1990 ( 300 Gt C) is less than estimates of carbon "sources" during this time frame. Sundquist's (1993) mean estimates are $\sim 220 \mathrm{Gt} \mathrm{C}$ from fossil fuel burning and $\sim 160 \mathrm{Gt} \mathrm{C}$ from changes in land use giving a total integrated carbon source of $\sim 380 \mathrm{Gt}$ C. The imbalance, $\sim 80 \mathrm{Gt} \mathrm{C}$, is believed to be larger than the uncertainties, and implies an additional sink in the terrestrial biosphere from increased plant fertilization by higher atmospheric $\mathrm{CO}_{2}$ and nitrate in the environment. Of course, this conclusion depends on how realistic the oceanic uptake estimates are.

\section{Acknowledgement}

This work was performed under the auspices of the U.S. Department of Energy Environmental Sciences Division by the Lawrence Livermore National Laboratory under contract No. W-7405-ENG-48. 
Table 1. Taxonomy of Ocean Carbon Cycle Models

\section{Classical multibox}

Minimum number of boxes is atmosphere, surface mixed layer deep sea). Single-box ocean fails because downward mixing is limited by thermocline diffusion bottleneck, not gas exchange at the surface.

\section{High-latitude surface box} Attempts to explain $p \mathrm{CO}_{2}$ variations in icecores though changes in circulation, solubility or biological carbon pumps leveraged by highlatitude gas exchange.

\section{Multiocean multibox}

Pandora and related models calibrated on tracers to include many physically distinct water mass regimes and process

\section{Box-diffusion}

Vertically-stacked boxes equivalent to pure diffusion finite-difference formulation beneath a well-mixed layer; steady state calibrated on prebomb radiocarbon.

\section{Outcrop-diffusion}

Combines diffusion with highlatitude connection to deep sea to simulate isopyncnal mixing outcrop.
Revelle and Suess, 1957; Bolin and Eriksson, 1959; Broecker et al., 1971; Machta, 1973; Hoffert, 1974; Keeling, and 1973, 1977; Bacastow and Keeling, 1973 Bjorkstrom, 1979; 1986; Broecker and Peng, 1982

Sarmiento and Toggweiler, 1984; Siegenthaler and Wenk, 1984; Knox, F., and M. McElroy, 1984; Volk and Hoffert, 1985; Toggweiler and Sarmiento, 1985; Volk and Liu, 1988.

Broecker and Peng, 1986, 1987; Bjorkstrom, 1986; Kier, 1988, 1989; Walker, 1991; Walker and Kasting, 1992

Oeschger et al., 1975;

Siegenthaler and Oeschger, 1978;

Hoffert et al. , 1979; Keeling et al., 1989a,b; Caldeira and Kasting, 1993

Siegenthaler, 1983 
Table 1 (continued). Taxonomy of Ocean Carbon Cycle Models

\section{Upwelling-diffusion and HLDA}

Classical deep sea recipes

for temperature and tracers up-

dated by circulation and mixing

connections to polar sea surface

plus surface and high-latitude

mixed layer

\section{GCM}

Transport by three-dimensional internal current fields, but vertical mixing input either as subgrid diffusivity or numerical diffusion; solutions depend on mixing assumptions

\section{Convolution integral}

A calculational method to estimate ocean carbon cycle model results without performing full model calculation.
Wyrtki, 1962; Munk, 1966; Hoffert et al., 1981; Volk, 1984; Shaffer, 1989; Khesghi et al., 1991; Siegenthaler and Joos, 1992; Jain et al., 1993;

Shaffer and Sarmiento, 1994

Sarmiento, 1986;

Maier-Reimer and Hasselmann, 1987;

Toggweiler et al., 1989a,b;

Maier-Reimer and Bacastow, 1990;

Bacastow and Maier-Reimer, 1990;

1992; Sarmiento et al., 1993

Maier-Reimer and Hasselmann, 1987;

Harvey, 1989; Wigley, 1991 
TABLE 2. Pre-industrial to present variation in the surface ocean of dissolved inorganic carbon $\left[\Sigma \mathrm{CO}_{2}\right]=\left[\mathrm{CO}_{2}\right]+\left[\mathrm{CO}_{3}{ }^{2-}\right]+\left[\mathrm{HCO}_{3}-\right]$ computed for constant total alkalinity $[\Sigma \mathrm{Alk}]=\left[\mathrm{HCO}_{3}^{-}\right]+2\left[\mathrm{CO}_{3}{ }^{2-}\right]+\left[\mathrm{H}_{2} \mathrm{BO}_{3}{ }^{-}\right]+\cdots+\left[\mathrm{OH}^{-}\right]-\left[\mathrm{H}^{+}\right]=2252 \mu \mathrm{eq} \mathrm{kg}-1$, $\left[\Sigma \mathrm{B}(\mathrm{OH})_{3}\right]=\left[\mathrm{B}(\mathrm{OH})_{3}\right]+\left[\mathrm{B}(\mathrm{OH})_{4}^{-}\right]$, water temperature $\mathrm{T}_{\mathrm{m}}=19.2^{\circ} \mathrm{C}$ and salinity $\mathrm{S}=$ $34.262 \%$ using the carbonate chemistry equilibrium constants in Peng et al. (1987).

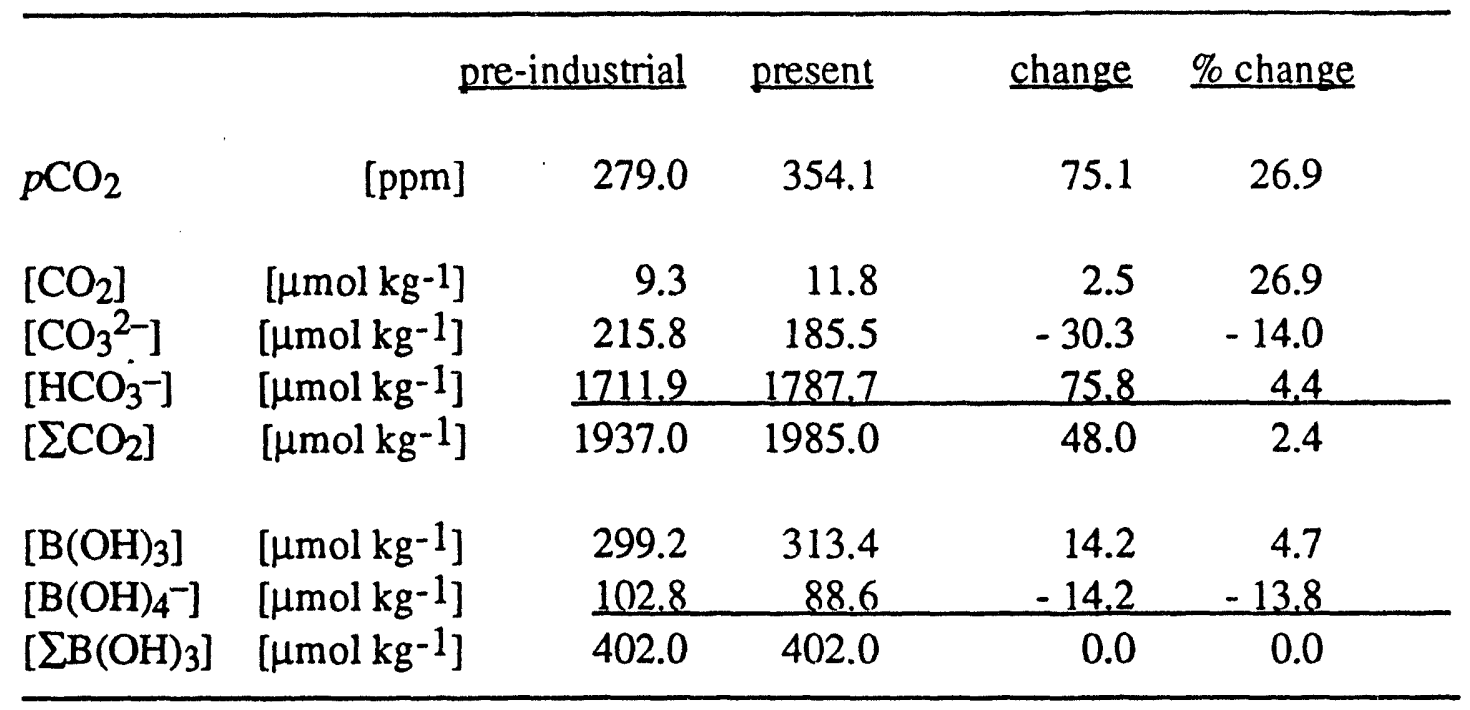


Figure Captions.

Fig. 1. Schematic diagram of the two-box ocean carbon cycle model described in the text.

Fig. 2. Comparison of the response of the two-box model described in the text with the results of Maier-Reimer and Hasselmann (1987) for a $\mathrm{CO}_{2}$ pulse equal to $25 \%$ of the pre-industrial atmospheric $\mathrm{CO}_{2}$ content.

Fig. 3. Schematic diagram of the three-box ocean carbon cycle model developed by Toggwiler and Sarmiento (1984).

Fig. 4. Schematic diagram of the PANDORA model developed by Broecker and Peng (1987). Shown are the names of the ten reservoirs, their fractional volumes and fractional outcrop areas, their temperatures, the fluxes of water between them, the rules governing the particulate cycles for organic matte, silica and silica, and the fluxes of organic carbon for the standard case.

Fig. 5. Schematic diagram of a box-diffusion model similar to that developed by Oeschger et al. (1975).

Fig. 6. From Schlesinger and Jiang (1990).

Fig. 7. Schematic diagram of an outcrop-diffusion model (Siegenthaler, 1983).

Fig. 8. Comparison of the box-diffusion (Siegenthaler and Oeschger, 1978) and outcrop-diffusion model (Siegenthaler, 1983) results for an anthropogenic $\mathrm{CO}_{2}$ emission scenario. Even though both models were calibrated using the same ${ }^{14} \mathrm{C}$ data, the model structure has a large effect on model results. It is thought that the box-diffusion model gives more accurate predictions than the outcrop-diffusion model. Curve 1 and 3, box- 
diffusion model; curves 2 and 4, outcrop-diffusion model. Solid curves, calibrated to natural $14 \mathrm{C}$; dashed curves, calibrated to bomb ${ }^{14} \mathrm{C}$. (From Siegenthaler, 1983)

Fig. 9. A schematic representation of an upwelling-diffusion model. The Hoffert et al. (1981) version considers a cold water box, but does not explicitly resolve it as a separate reservoir. The HILDA model (Shaffer, 1989;; Siegenthaler and Joos, 1992) divides the polar water box into two explicit reservoirs and considers mixing transport between the deep polar water box and all levels in the one-dimensional deep ocean compartment. 


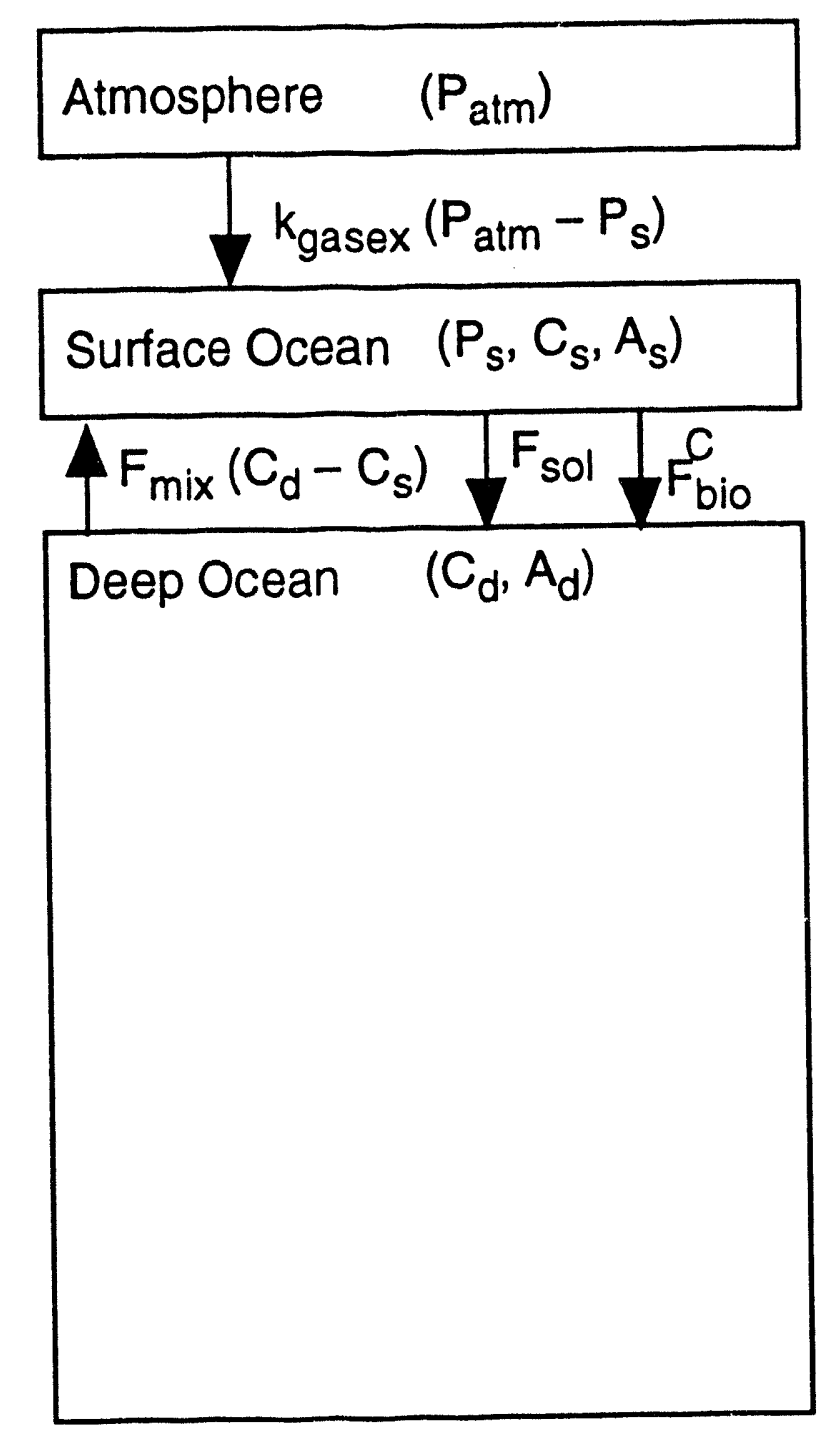

Fig 1 . 


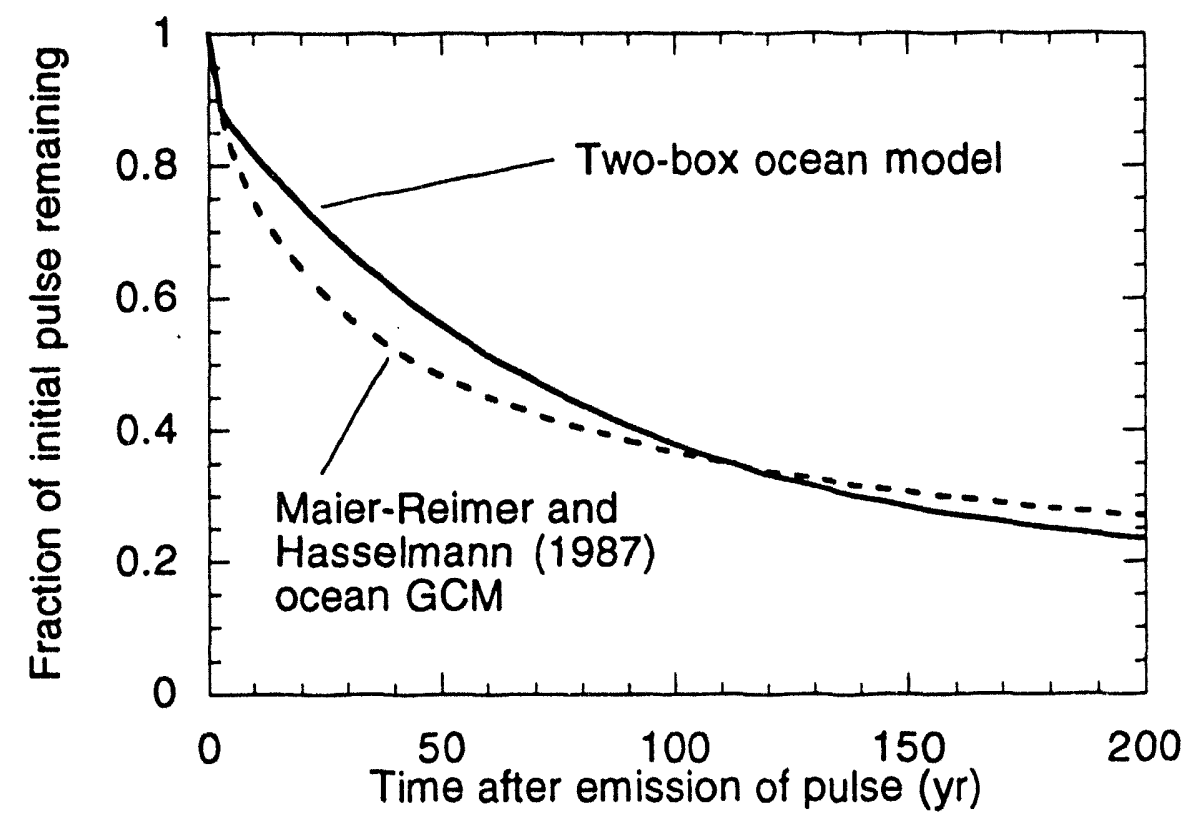

Fig 2 


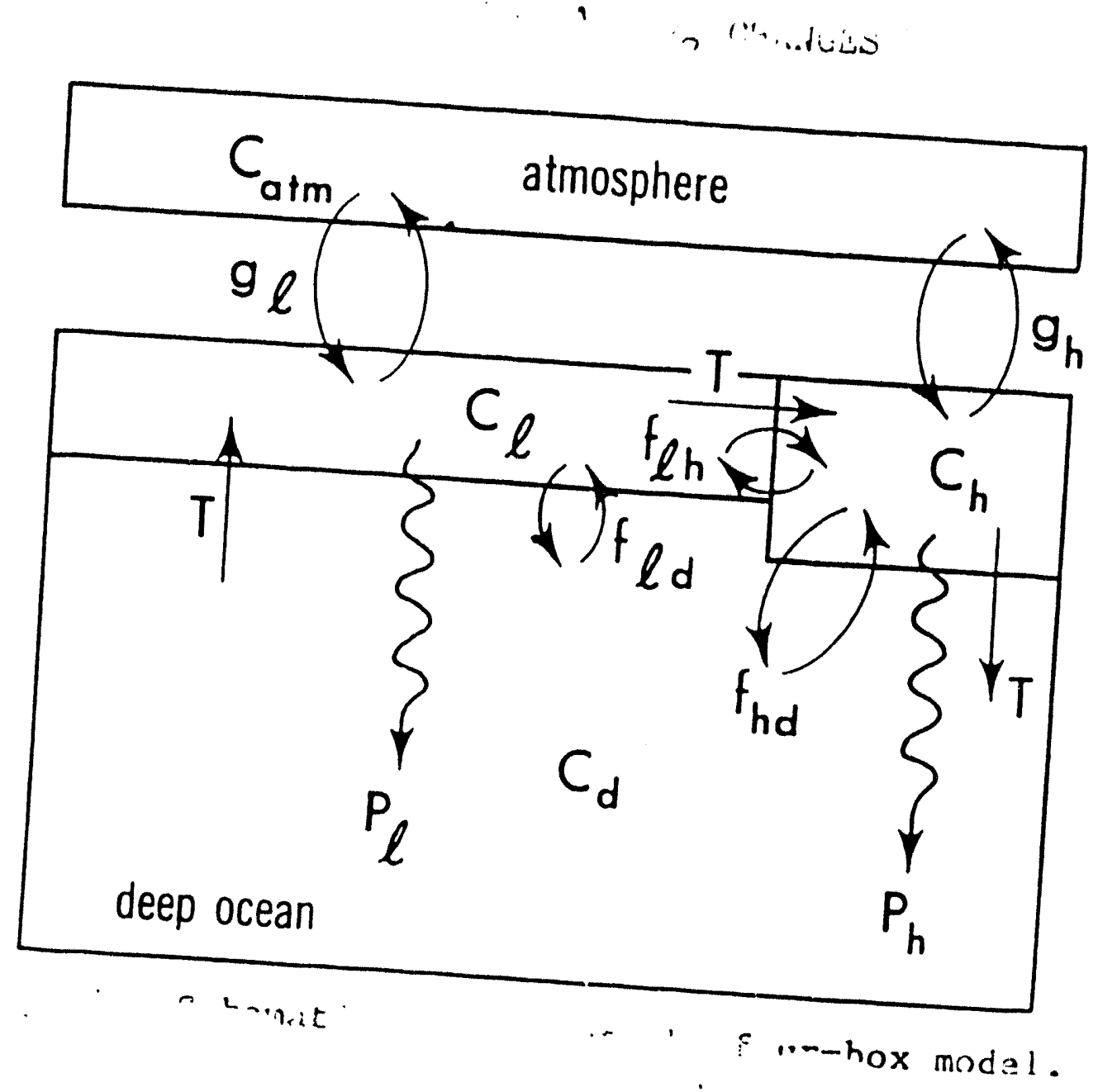

F.g 3 . 

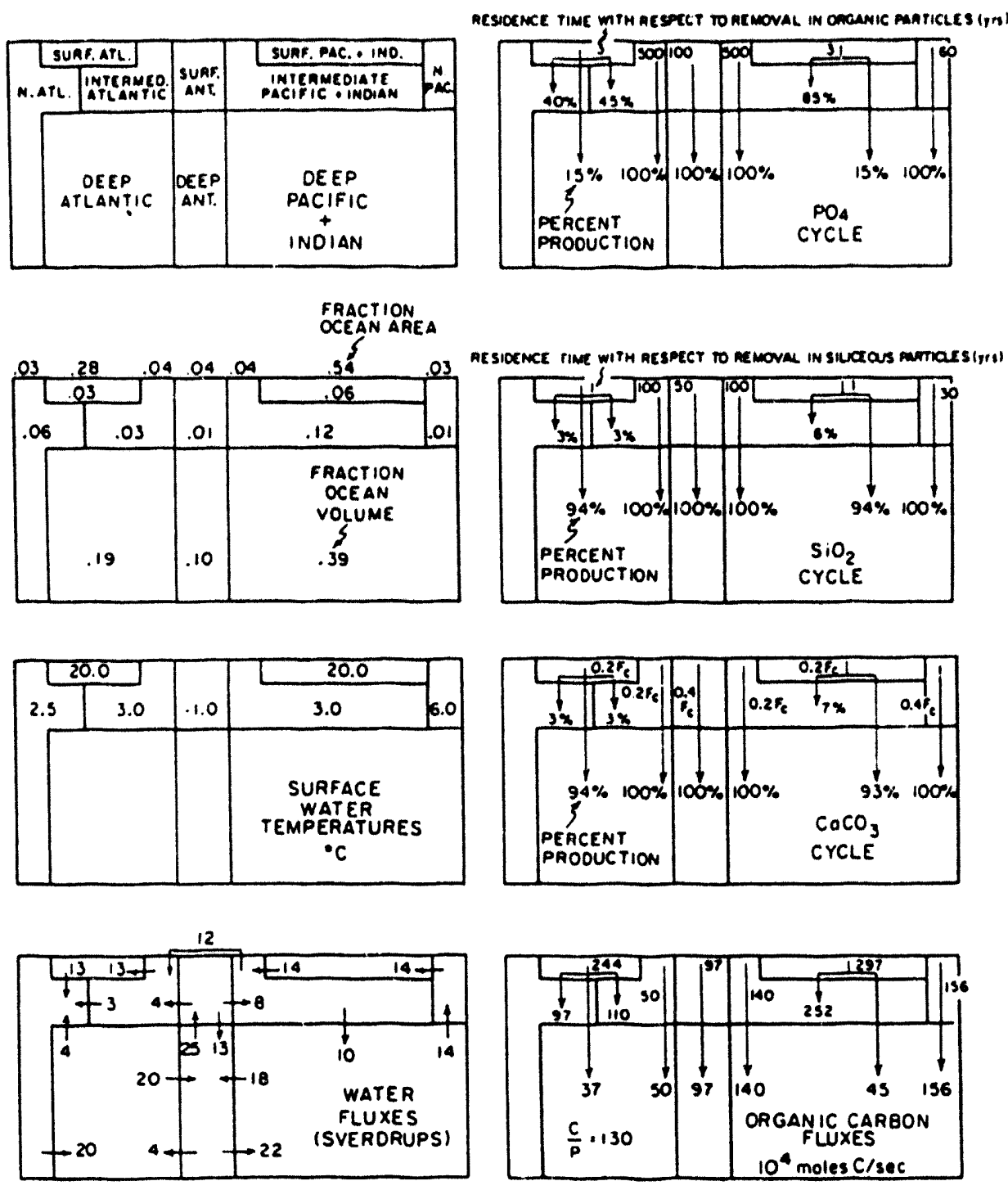

Fig 4 


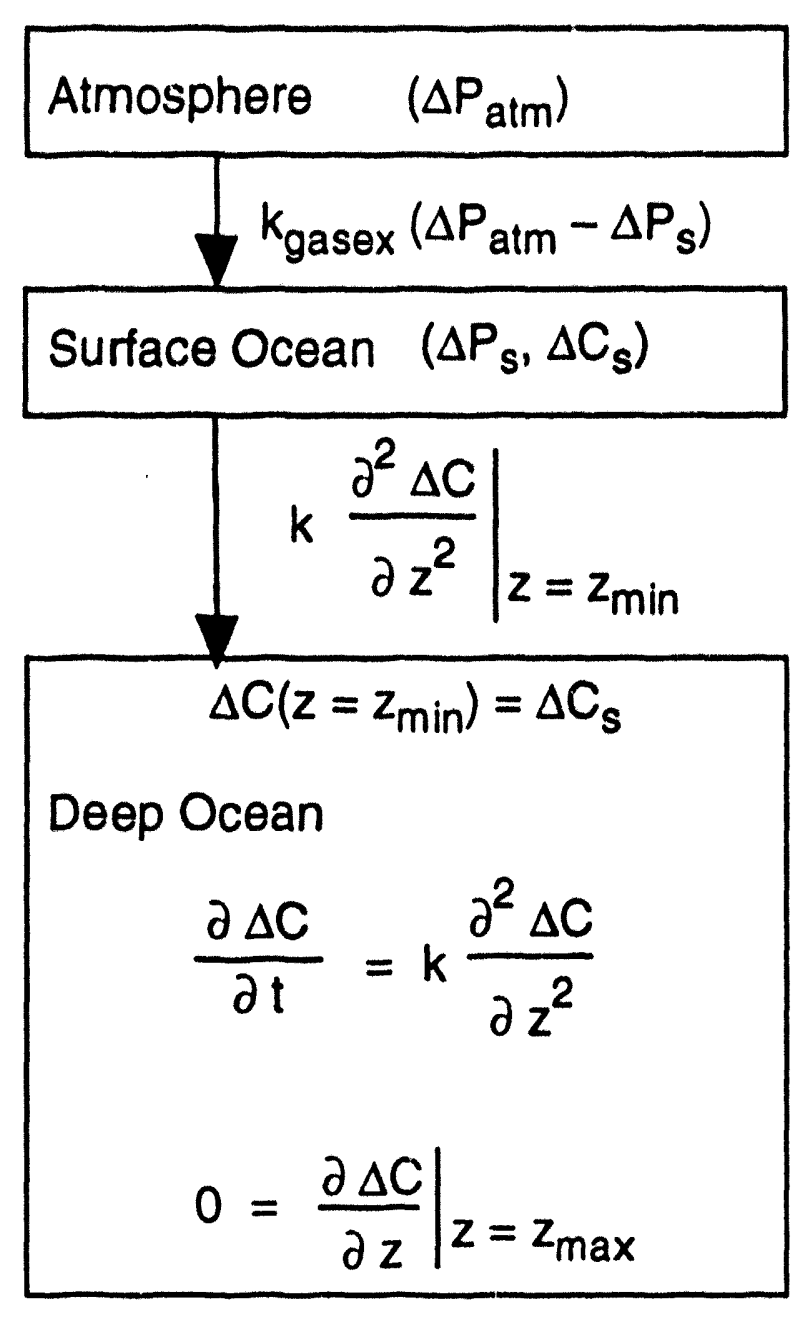

Fig 5 


\section{(4177peces))}

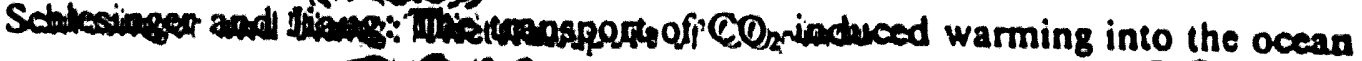
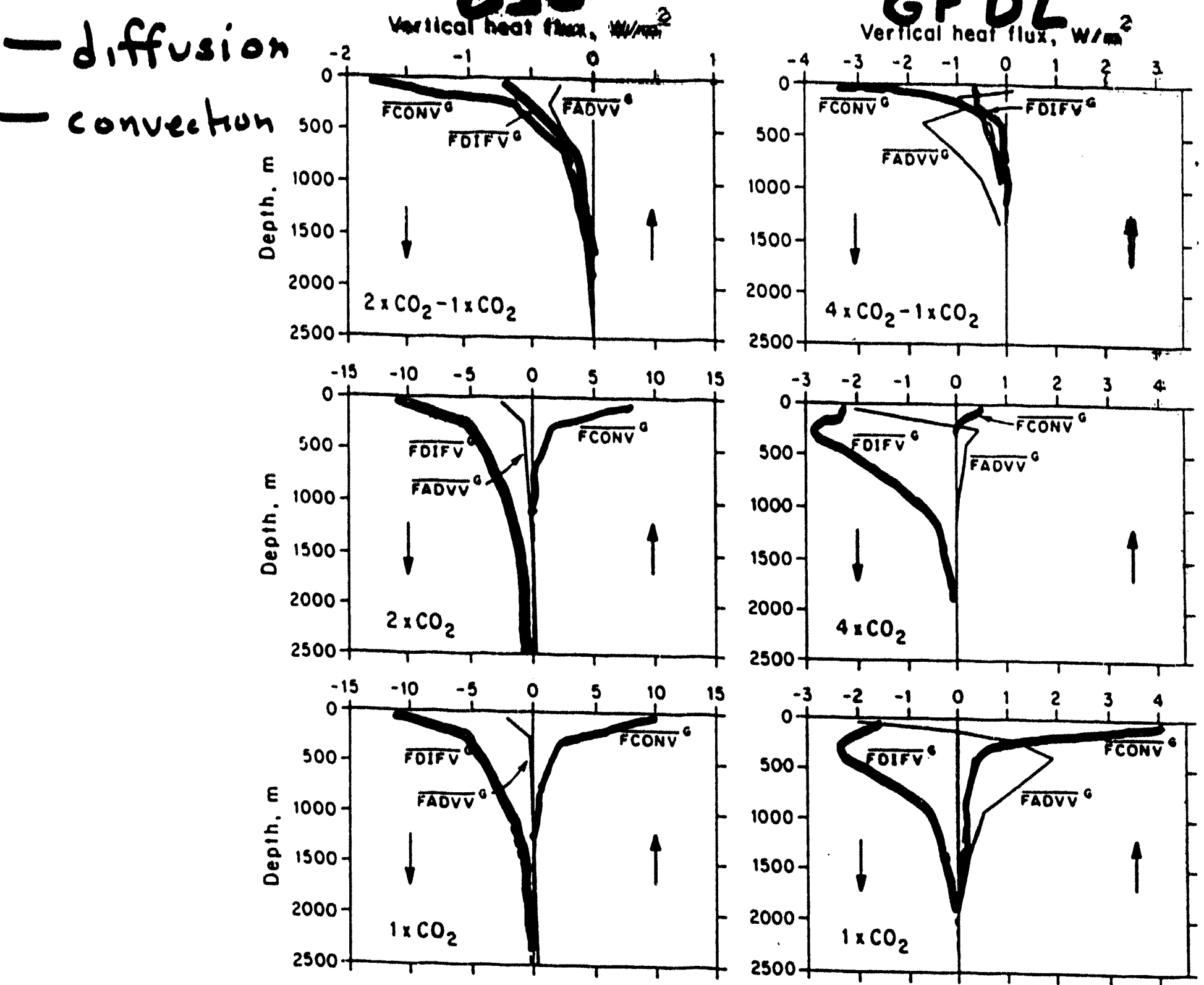

(a)

(b)

Fig. 6a and b. Annual global-mean heat nux by advection ( $\triangle \vec{F} \overline{A D V V})$. diffusion $(A F D T F V$ and cunvection $(\triangle F C O N V)^{6}$ for a year 12 or the OSU $2 \times \mathrm{CO}_{2}-1 \times \mathrm{CO}_{2}$ difference (upper panel). $2 \times \mathrm{CO}_{2}$ (middle panel) and $\mathrm{I} \times \mathrm{CO}_{2}$ (lower panel) simulations and b years $20-30$ of the GFDL. $4 \times \mathrm{CO}_{2}-1 \times \mathrm{CO}_{2}$ difference (upper panel), $4 \times \mathrm{CO}_{2}$ (middle panel) and $1 \times \mathrm{CO}_{2}$ (lower panel) simulations from Bryan and Spelman (1985)

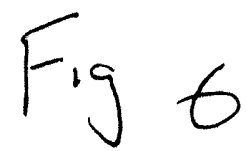


MILER: Rr " $\mathrm{CO}_{2}$ Sr innSIUM

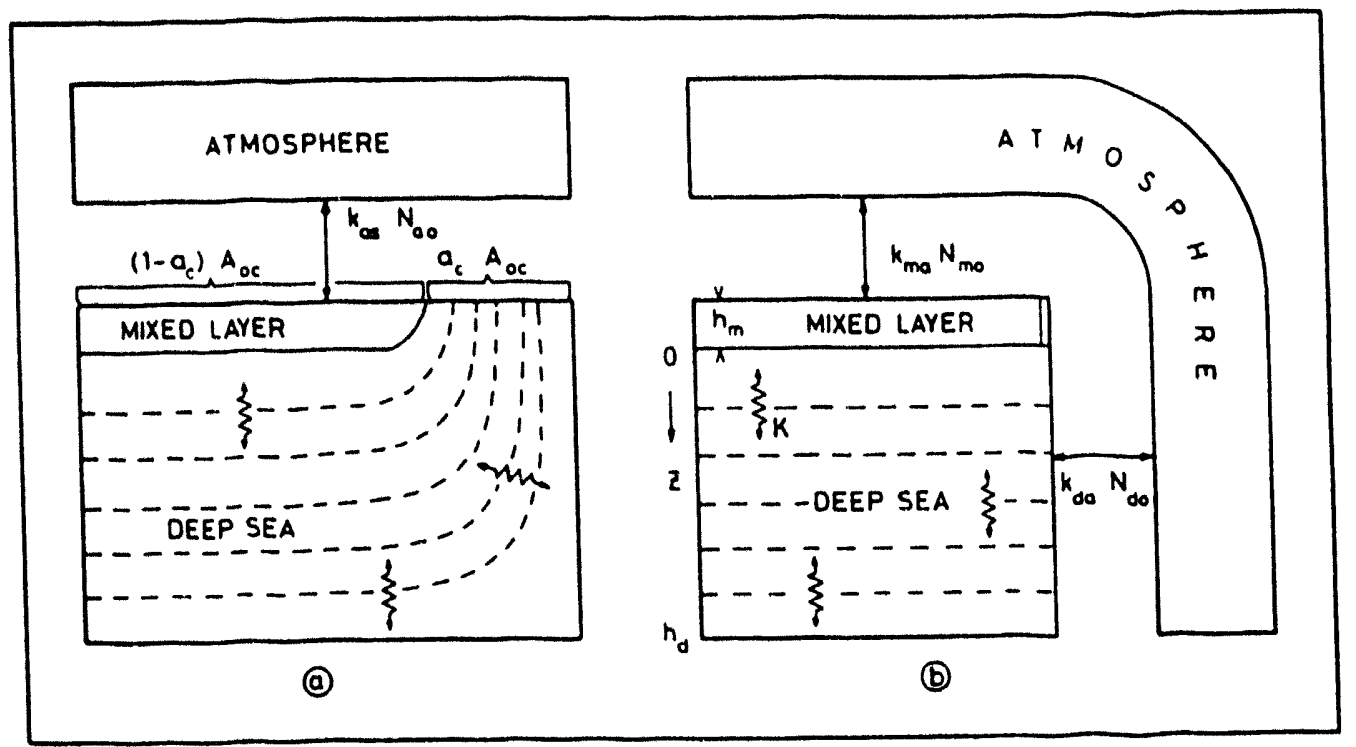

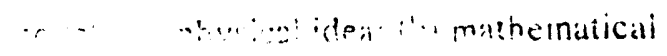

Fig 7 


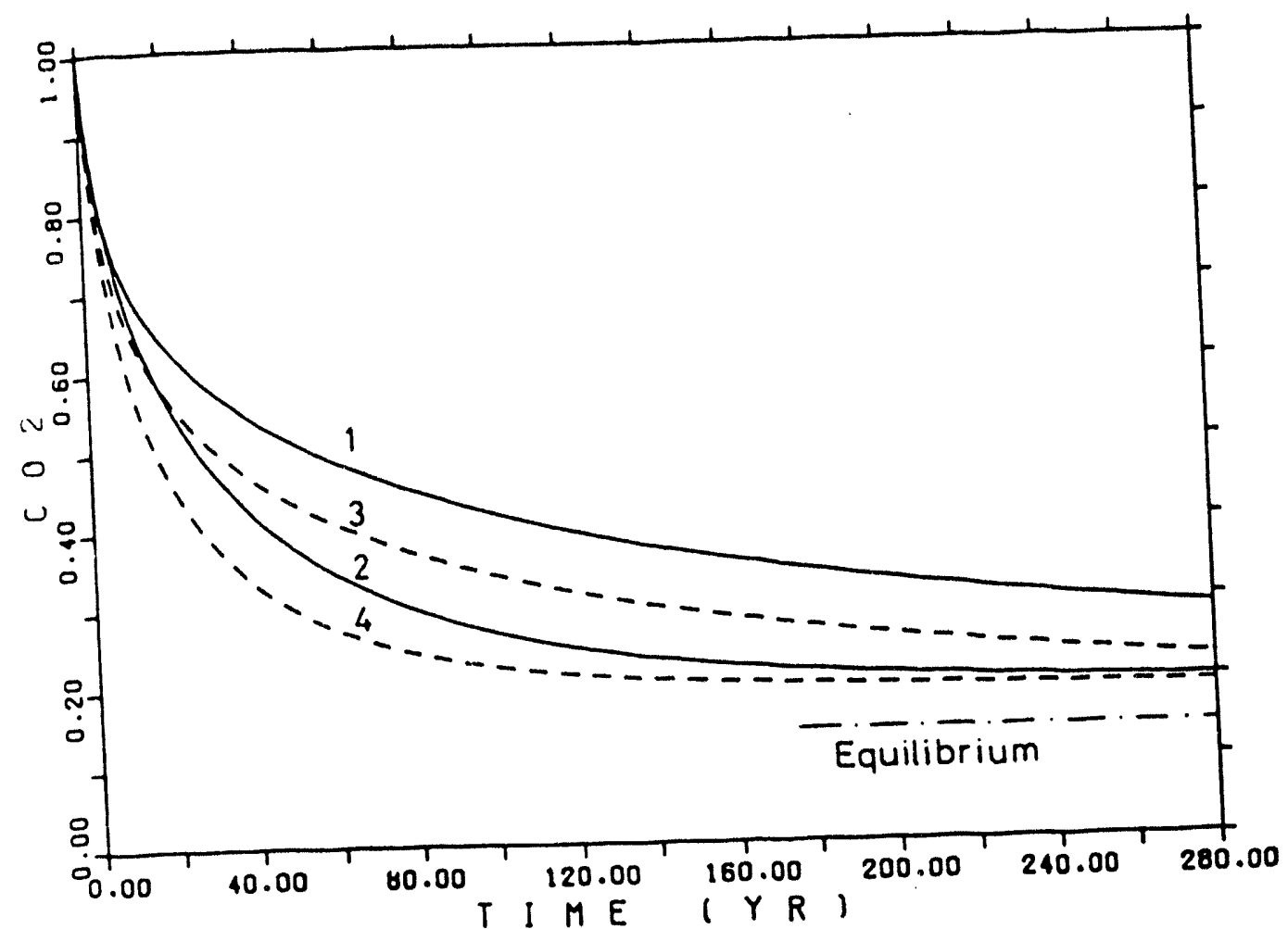

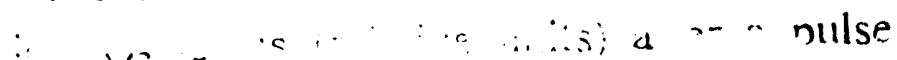

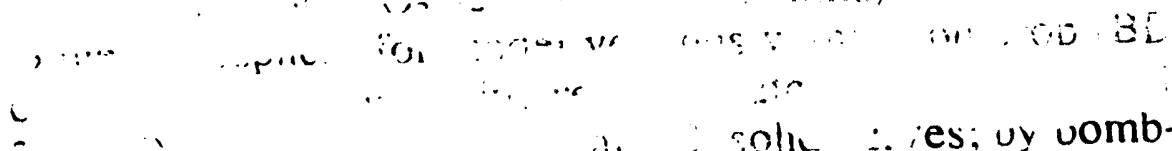

$\therefore$ - soh $\therefore$ ies; uy uomb-

Fig 8 

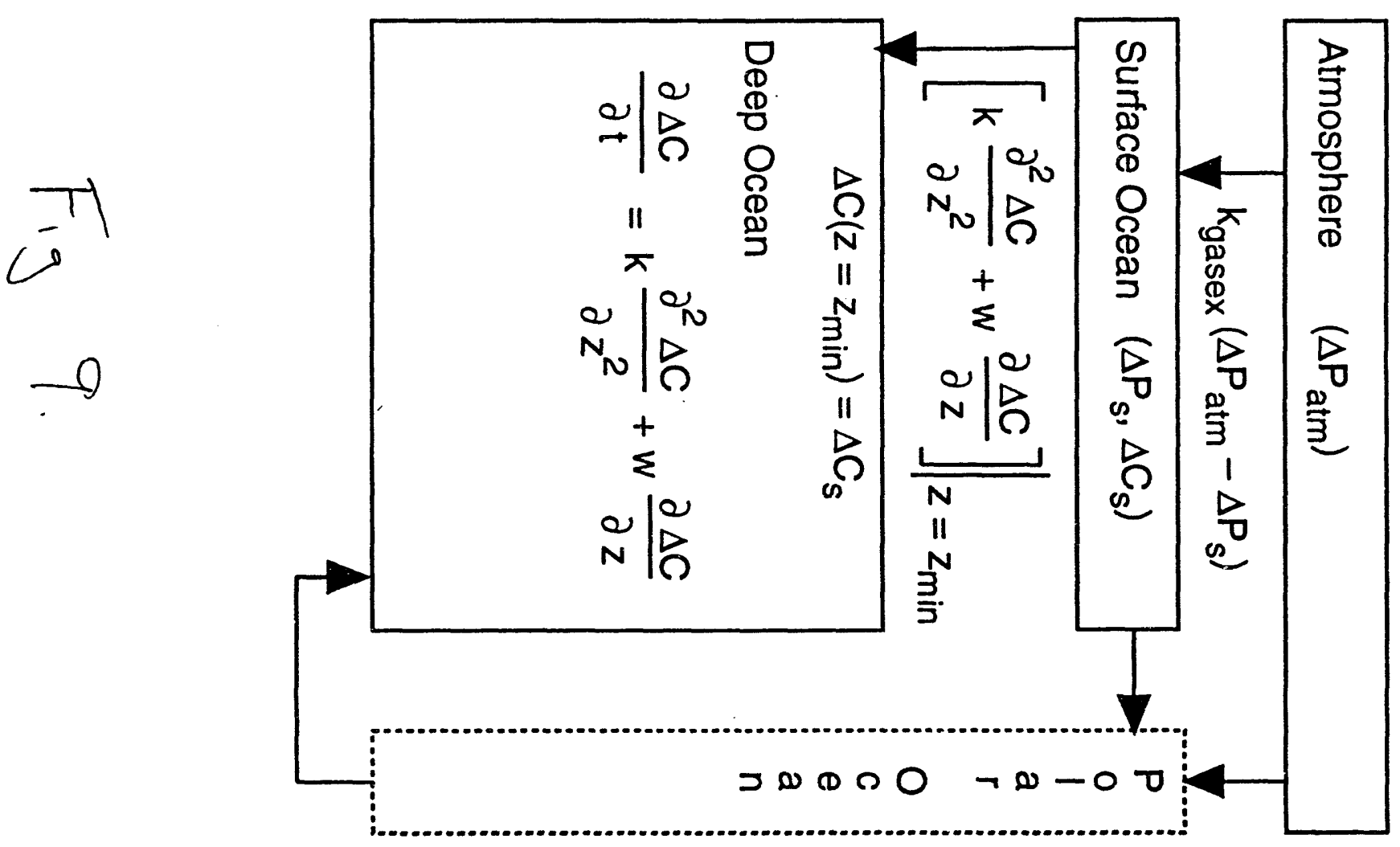


\section{REFERENCES}

Bacastow, R. and E. Maier-Reimer, "Dissolved organic carbon in modeling oceanic new production", Global Biogeochemical Cycles, vol. 5, pp. 71-85, 1991.

Bacastow, R., and C.D. Keeling (1973) Atmospheric carbon dioxide and radiocarbon on the natural carbon cycle. In Carbon and the Biosphere, edited by G.M. Woodwell and E.V. Pecan, U.S. Atomic Energy Commission, pp 86-135. (Available as CONF720510 from Natl. Tech. Inf. Serv., Springfield, Va.)

Bacastow, R., and E. Maier-Reimer (1990) Ocean circulation model of the carbon cycle. Clim Dyn., 4, 95-125.

Bacastow, R., and Maier-Reimer (1992) Dissolved organic carbon in modeling ocean new production. Global Biogeochem. Cycles, 5, 71-78.

Banse, K., "Grazing, temporal changes of phytoplankton concentrations, and the microbial loop in the open sea", In: Primary Productivity and Biogeochemical Cycles in the Sea, P.G. Falkowski and A.D. Woodhead (eds.), Plenum, New York, 1992.

Bjorkstrom, A. (1979) A model of $\mathrm{CO}_{2}$ interaction between atmosphere, oceans and land biota. In The Global Carbon Cycle, SCOPE 13, edited by B. Bolin et al., John Wiley, NY, pp. 403-457.

Bjorkstrom, A. (1986) One-dimensional and two-dimensional ocean models for predicting the distribution of $\mathrm{CO}_{2}$ between the ocean and the atmosphere. In The Changing Carbon Cycle, edited by J.R. Trabalka and D.E. Reichle, Springer-Verlag, NY, pp. 258-278.

Bolin, B. (1977) Modeling the the oceans and ocean sediments and their response to fossil fuel carbon dioxide emissions. In The Fate of Fossil Fuel $\mathrm{CO}_{2}$ in the Oceans, edited by N.R. Anderson and A. Malahoff, Plenum, NY, pp. 81-95.

Bolin, B., and E. Eriksson (1959) Changes in the carbon content of the atmosphere and sea due to fossil fuel combustion. In The Atmosphere and Sea in Motion, edited by B. Bolin, Rockefeller Institute Press, New York.

Broecker, W.S., and T. Takahashi (1978) The relationship between lysocline depth and in situ carbonate ion concentration. Deep Sea Res., 25, 65-95.

Broecker, W.S., and T.-H. Peng (1982)Tracers in the Sea. Eldegio Press, LamontDoherty Geological Observatory, Palisades, NY, 691 pp.

Broecker, W.S., and T.-H. Peng (1986) Carbon cycle 1985, glacial to interglacial changes in the operation of the global carbon cycle. Radiocarbon, 28 (2A), 309-327.

Broecker, W.S., and T.-H. Peng (1987) The role of $\mathrm{CaCO}_{3}$ compensation in the glacial to interglacial atmospheric $\mathrm{CO}_{2}$ change. Global Biogeochem. Cycles, 1, 15-39. 
Broecker, W.S., R. Gerard, M.Ewing and B.C. Heezen (1960) Natural radiocarbon in the Atlantic Ocean. J. Geophys. Res., 65, 2903-2931.

Broecker, W.S., T.-H. Peng, G. Ostlund and M. Stuiver (1985) The distribution of bomb radiocarbon in the ocean. J. Geophys. Res., 90, 6953-6970.

Broecker, W.S., Y.-H. Li and T.-H. Peng (1971) Carbon dioxide -- man's unseen artifact. In Impingment of Man on the Oceans, edited by D.W. Hood, Wiley-Interscience, NY, pp. 287-324.

Butler, J.N. (1991) Carbon Dioxide Equilibria and their Applications. Lewis Publishers, Chelsea, MI, 255 pp.

Caldeira, K. and Kasting, J.F., Insensitivity of global warming potentials to carbon dioxide emission scenarios, Nature 366, 251-253, 1993.

Caldeira, K. and Rampino, M.R., Biogeochemical stabilization of the carbon cycle and climate after the Cretaceous/Tertiary boundary mass extinction events, Paleoceanography 8, 515-525, 1993.

Craig, H. (1969) Abyssal radiocarbon in the Pacific. J. Geophys. Res., 74, 5491-5501.

Donaghay, P.L., Liss, P. S., Duce, R. A., Kester, D. A., Hanson, A. K., Villareal, T., Tindale, N., and Gifford, D., J., "The role of episodic atmospheric nutrient inputs in the chemical and biological dynamics of ocean ecosystems", Oceanography, vol. 4, pp. 62-70, 1991.

Enting, I.G., and G.I. Pearman (1987) Description of a one-dimensional carbon cycle model calibrated by the techniques of constrained inversion. Tellus, 39B, 459-476.

Eppley, R.W. (1984) Relations between primary productivity and ocean chlorophyll determined by satellite. In Global Ocean Flux Study (GOFS), Woods Hole Oceanogr. Inst., Woods Hole, MA, pp. 85-102.

Fasham, M.R.J. (1993) Modelling the oceanic biota. In The Global Carbon Cycle, edited by M. Heimann, Springer-Verlag, New York (in press).

Fasham, M.J.R., J.L. Sarmiento, R.D. Slater, H.W. Ducklow, and R. Williams, "Ecosystem behavior at Bermuda Station 'S' and ocean weather station 'India': A general circulation model and observational analysis", Glob. Biogeochem. Cycles, vol. 7, pp. 379-415, 1993.

Harvey, L.D.D. (1989) Managing atmospheric $\mathrm{CO}_{2}$. Clim. Change, 15, 343-381.

Hoffert, M.I. (1974) Global distributions of atmospheric carbon dioxide in the fossil fuel era: A projection. Atmospheric Environment 8, 1225-1249.

Hoffert, M.I., A.J. Callegari and C.-T. Hseih (1981) A box-diffusion carbon cycle model with upwelling, polar bottom water formation and a marine biosphere. In Carbon Cycle Modeling, SCOPE 16, edited by B.Bolin, John Wiley, NY, pp. 287-305. 
Hoffert, M.I., and W.S. Broecker (1978) Apparent vertical eddy diffusion rates in the pycnocline of the Norwegian Sea as determined from the vertical distribution of tritium. Geophys. Res. Lett., 5, 502-504.

Hoffert, M.I., Y.-C. Wey, A.J. Callegari and W.S. Broecker (1979) Atmospheric response to deep-sea injections of fossil-fuel carbon dioxide. Clim. Change, 2, 53-68.

Holland, D. M., Mysak, L. A., and Oberhuber, J. M., "Sensitivity study of a dynamic thermodynamic sea ice model", J. Geophys., Res., vol. 98, pp. 2561-2586, 1993.

Intergovernmental Panel on Climate Change,Climate Change: The IPCC Scientific Assessment., University Press, Cambridge, 365 pp., 1990.

Jain, A.K., Wuebbles, D.J., Kheshgi, H., and Hoffert, M.I. (1993) Estimates of atmospheric fossil fuel $\mathrm{CO}_{2}$ and bomb radiocarbon from a schematic carbon cycle model. Presented at AGU 1993 Fall Meeting, abstract in Eos, October 26, 1993 supplement, p. 163

Joos, F., J.R. Sarmiento and U. Siegenthaler (1991) Estimates of the effect of Southern Ocean iron fertilization on atmospheric $\mathrm{CO}_{2}$ concentrations. Nature, 349, 772-775.

Keeling, C.D. (1973) The carbon dioxide cycle: Reservoir models to depict the exchange of atmospheric carbon dioxide with the oceans and land plants. In Chemistry of the Lower Atmosphere, edited by S.I. Rasool, Plenum, NY, pp. 251-329.

Keeling, C.D. (1977) Impact of industrial gases on climate. In Energy and Climate, Geophysics Study Committee, National Academy of Sciences, Washington, DC, pp. $72-91$.

Keeling, C.D., R.B. Bacastow, A.F. Carter, S.C. Piper, T.P. Whorf, M. Heimann, W.G. Mook and $\mathrm{H}$. Roeloffzen (1989a) A three-dimensional model of atmospheric $\mathrm{CO}_{2}$ transport based on observed winds. 1. Analysis of observational data. In Aspects of Climate Variability in the Pacific and Western Americas. Geophys. Monog. 55, edited by D.H. Peterson, Am. Geophys. Union, Washington, DC, pp. 165-236.

Keeling, C.D., S.C. Piper and M. Heimann (1989b) A three-dimensional model of atmospheric $\mathrm{CO}_{2}$ transport based on observed winds. 4. Mean annual gradients and interannual variations. In Aspects of Climate Variability in the Pacific and Western Americas. Geophys. Monog. 55, edited by D.H. Peterson, Am. Geophys. Union, Washington, DC, pp. 305-363.

Keeling, R.F., and S.R. Shertz (1992) Seasonal and interannual variations in atmospheric oxygen and implications for the global carbon cycle. Nature, 358, 723-727.

Keir, R.S. (1988) On the late Pleistocene ocean geochemistry and circulation. Paleoceanography, 3, 443-445. 
Keir, R.S. (1989) Paleoproduction and atmospheric $\mathrm{CO}_{2}$ based on ocean modeling. In Productivity of the Ocean: Past and Present, edited by W.H. Berger, V.S. Smetacek and G. Wefer, John Wiley \& Sons, NY, pp. 395-406.

Khesghi, H.S., B.P. Flannery and M.I. Hoffert (1991) Marine biota effects on the compositional structure of the world oceans. J. Geophys. Res., 96, 4957-4969.

Killough, G.G., and W.R. Emanuel, A comparison of several models of carbon turnover in the ocean with respect to their distributions of transit time and age, and response to atmospheric $\mathrm{CO}_{2}$ and ${ }^{14} \mathrm{C}$, Tellus 33, 274-290, 1981.

Knox, F., and M. McElroy (1984) Changes in atmospheric $\mathrm{CO}_{2}$ : influence of the marine biota at high latitudes. J. Geophys. Res., 89, 4629-4637.

Lashof, D.A., and D.R. Ahuja, Relative contributions of greenhouse gas emissions to global warming, Nature 344, 529-531, 1990.

Levitus, S., Climatological Atlas of the World Ocean, NOAA Professional Paper 13, U.S. Government Printing Office, Washington, DC, 1982.

Machta, L. (1973) The role of the oceans and biosphere in the carbon cycle. In The Changing Chemistry of the Oceans, edited by D. Dryssen and D. Jagner, WileyInterscience, New York, pp. 121-145.

Maier-Reimer, E., and K. Hasselmann (1987) Transport and storage of $\mathrm{CO}_{2}$ in the ocean - An inorganic ocean-circulation carbon cycle model. Clim Dyn., 2, 63-90.

Maier-Reimer, E., and R. Bacastow (1990) Modeling of geochemical tracers in the ocean. In Climate-Ocean Interaction, edited by M.E. Schlesinger, Kluwer Academic Publishers, Dordrecht, The Netherlands, pp. 233-267.

Maier-Reimer, E., Geochemical cycles in an ocean general circulation model. Preindustrial Tracer Distributions, Glob. Biogeochem. Cycles, vol. 7, pp. 645 - 677, 1993.

Maier-Reimer, E., Mikolajewicz, U., and Hasselmann, K., Mean circulation of the Hamburg LSG OGCM and its sensitivity to the thermohaline surface forcing, J. Phys. Oceanogr., vol. 23, pp. 731-757, 1993.

Manabe, S., and Stouffer, R. J., "Century-scale effects of increased atmospheric $\mathrm{CO}_{2}$ on the ocean atmosphere system", Nature, vol. 364, pp. 215 - 218, 1993.

Martin, J.H., "Iron, Liebig's Law, and the greenhouse", Oceanography, vol. 4, pp. 52-55, 1991.

Miller, C.B., Frost, B. W., Booth, B., Wheeler, P. A., Landry, M. R., and Welschmeyer, N., "Ecological processes in the subarctic Pacific: Iron limitation cannot be the whole story", Oceanography, vol. 4, pp. 71-78, 1991. 
Moore III, B., and A. Bjorkstrom (1986). Calibrating ocean models by the constrained inverse method. In The Changing Carbon Cycle, edited by J.R. Trabalka and D.E. Reichle, Springer-Verlag, NY, pp. 295-328.

Munk, W.H. (1966) Abyssal receipes, Deep Sea Res., 13, 707-736.

Najjar, R.G. (1992) Marine biogeochemistry. In Climate System Modeling, edited by K. Trenberth, Cambridge University Press, NY, pp. 241-280.

Najjar, R. G., Sarmiento, J. L., anf Toggweiler, J. R., Downward transport and fate of organic matter in the ocean: simulations with a general circulation model, Glob. Biogeochem. Cycles, vol. 6, pp. 45-76, 1990.

Nydal, R. and K. Lovseth (1983) Tracing bomb ${ }^{14} \mathrm{C}$ in the atmosphere 1962-1980. J. Geophys. Res., 88, 3621-3642.

Oeschger, H., U. Seigenthaler, U. Schotterer and A. Guglemann (1975) A box-diffusion model to study the carbon dioxide exchange in nature. Tellus, 27, 168-192.

Parsons, T.R., Takahashi, M. and B. Hargrave (1984) Biological Oceanographic Processes, Pergammon Press, Elmsford, NY, 330 pp.

Peng, T.-H., T. Takahashi, W.S. Broecker and J. Olafsson (1987) Seasonal variability of carbon dioxide, nutrients and oxygen in the northern North Atlantic surface water, Tellus, 39B, 439-458.

Peng, T.-H., W.S. Broecker, G.G. Mathiew, Y.-H. Li and A.E. Bainbridge (1979) Radon evasion rates in the Atlantic and Pacific Oceans as determined during the GEOSECS program. J. Geophys. Res., 84, 2471-2486.

Redfield, A.C., B.H. Ketchem and F.A. Richards (1963) The influence of organisms on the composition of sea-water. In The Sea, Vol. 2, edited by M.N. Hill, Interscience Publishers, NY, pp. 26-77.

Revelle, R. and H.E. Suess (1957) Carbon dioxide exchange bewteen the atmosphere and the ocean and the question of an increase of $\mathrm{CO}_{2}$ during the past decades. Tellus, 9 , 18-27.

Sarmiento, J.L. (1986) Three-dimensional ocean models for predicting the distribution of $\mathrm{CO}_{2}$ between the ocean and atmosphere. In The Changing Carbon Cycle, edited by J.R. Trabalka and D.E. Reichle, Springer-Verlag, NY, pp. 279-294.

Sarmiento, J.L., R.D. Slater, M.J.R. Fasham, H.W. Ducklow, J.R. Toggweiller, and G.T. Evans, A seasonal three-dimensional ecosystem model of nitrogen cycling in the north Atlantic euphotic zone, Glob. Biogeochem. Cycles, vol. 7, pp. 417-450, 1993. Sarmiento, J.L. and J.R. Toggweiler (1984) A new model for the role of the oceans in determining atmospheric $p \mathrm{CO}_{2}$. Nature, 308, 621-624. 
Sarmiento, J.L., J.C. Orr, and U. Siegenthaler (1992) A perturbation simulation of $\mathrm{CO}_{2}$ uptake in an ocean general circulation model. J. Geophys. Res., 97, 3621-3645.

Sarmiento, J.L., R.D. Slater, M.J.R. Fasham, H.W. Ducklow, J.R. Toggweiler and G.T. Evans (1993) A seasonal three-dimensional ecosystem model of nitrogen cycling in the North Atlantic euphotic zone. Global Biogeochem. Cycles, 7, 417-450.

Schlesinger, M.E., and X. Jiang, Simple inodel representation of atmosphere-ocean GCMs and estimation of the time scale of $\mathrm{CO}_{2}$-induced climate change. J. Clim, 3, 1297-1315, 1990.

Seigenthaler, U., and Sarmiento, J. L., Atmospheric carbon dioxide and the ocean, Nature, vol. 365, pp. $119-1125,1993$.

Shaffer, G. (1989) A model of biogeochemical cycling of phosphorous, nitrogen, oxygen and sulfur in the ocean: One step toward a global climate model. J. Geophys. Res., 94, 1979-2004.

Shaffer, G. and J.L. Sarmiento (1994) Biogeochemical cycling in the global ocean 1: A new, analytical model with continuous vertical resolution and high latitude dynamics. J. Geophys. Res. (in press).

Shine, K.P., R.G. Derwent, D.J. Wuebbles, and J-J. Morcrete, Radiative forcing of climate, in, Climate Change - The IPCC Scientific Assessment, edited by J.T. Houghton, G.J. Jenkins, and J.J. Ephraums, pp. 41-68, Cambridge Univ. Press, New York, 1990.

Siegenthaler, U. (1983) Uptake of excess $\mathrm{CO}_{2}$ by an outcrop-diffusion model of the ocean. J. Geophys. Res., 88, 3599-3608.

Siegenthaler, U., and F. Joos (1992) Use of a simple model for studying oceanic tracer distributions and the global carbon cycle. Tellus, 44B, 186-207.

Siegenthaler, U., and H. Oeschger (1978) Predicting future atmospheric carbon dioxide levels. Science, 199, 388-395.

Siegenthaler, U., and $\mathrm{H}$. Oeschger (1987) Biospheric $\mathrm{CO}_{2}$ emissions during the past 200 years reconstructed by deconvolution of ice core data. Tellus, 39B, 140-154.

Siegenthaler, U., and H. Oeschger, Predicting future atmospheric carbon dioxide levels, Science 199, 388-396, 1978.

Siegenthaler, U., and J.L. Sarmiento (1993) Atmospheric carbon dioxide and the ocean. Nature (in press).

Siegenthaler, U., and T. Wenk (1984) Rapid atmospheric $\mathrm{CO}_{2}$ variations and ocean circulation. Nature, 308, 624-626.

Stumm, W. and J.J. Morgan, Aquatic Chemistry, 2nd Edition, 780 p., John Wiley and Sons, 1981. 
Sundquist, E.T. (1993) The global carbon dioxide budget. Science, 259, 934-940.

Sundquist, E.T., Steady- and non-steady-state carbonate-silicate controls on atmospheric $\mathrm{CO}_{2}$, Quat. Sci. Rev. 10, 283-296, 1990.

Tans, P.P., I.Y. Fung and T. Takahashi (1990) Observational constraints on the global atmsopheric $\mathrm{CO}_{2}$ budget. Science, 247, 1431-1438.

Toggweiler, J.R., and J. Sarmiento (1985) Glacial to interglacial changes in atmospheric carbon dioxide: the critical role of ocean surface water at high latitudes. In The Carbon Cycle and Atmospheric $\mathrm{CO}_{2}$ : Natural Variations Archean to Present, Geophys. Monog. 32, edited by E. Sundquist and W.S. Broecker, Am. Geophys. Union, Washington, DC, pp. 163-184.

Toggweiler, J.R., K. Dixon, and K. Bryan (1989a) Simulations of radiocarbon in a coarse resolution world ocean model 1. Steady state prebomb distributions. J. Geophys. Res. 94, 8217-8242.

Toggweiler, J.R., K. Dixon and K. Bryan (1989b) Simulations of radiocarbon in a coarse resolution world ocean model 1. Distributions of bomb-produced carbon-14. J. Geophys. Res. 94, 8243-8264.

Volk, T. (1984) Multi-property modeling of the marine biosphere in relation to global climate and carbon cycles. Ph.D. thesis, N. Y. Univ., University Microfilms International, Ann Arbor, MI, 348 pp.

Volk, T. and Z. Liu (1988) Controls of $\mathrm{CO}_{2}$ sources and sinks in the Earth scale surface ocean: Temperature and nutrients. Global Biogeochem. Cycles, 2, 73-89.

Volk, T., and M.I. Hoffert (1985) Ocean carbon pumps: Analysis of relative strengths and efficiencies in ocean-driven atmospheric $\mathrm{CO}_{2}$ changes. In The Carbon Cycle and Atmospheric $\mathrm{C.O}_{2}$ : Natural Variations Archean to Present, Geophys. Monog. 32, edited by E. Sundquist and W.S. Broecker, Am. Geophys. Union, Washington, DC, pp. 91-110.

Walker, J.C.G. (1991) Numerical Adventures with Geochemical Cycles. Oxford University Press, NY, 192 pp.

Walker, J.C.G., and J.F. Kasting (1992) Effect of fuel and forest conservation on future levels of atmospheric carbon dioxide. Palaeogeogr., Palaeoclimatol., Palaeoecol., 97, 151-189.

Watson, R.T., H. Rodhe, H. Oeschger and U. Siegenthaler (1990) Greenhouse gases and aerosols. In Climate Change: The IPCC Scientific Assessment, edited by J.T. Houghton, G.J. Jenkins and J.J. Ephraums, Cambridge University Press, NY, pp. 140. 
Wigley, T.M.L. (1991) A simple inverse carbon cycle model. Global Biogeochem. Cycles, 5, 373-382.

Wyrtki, K. (1962) The oxygen minimum in relation to ocean circulation. Deep Sea Res., 9, 11-23. 

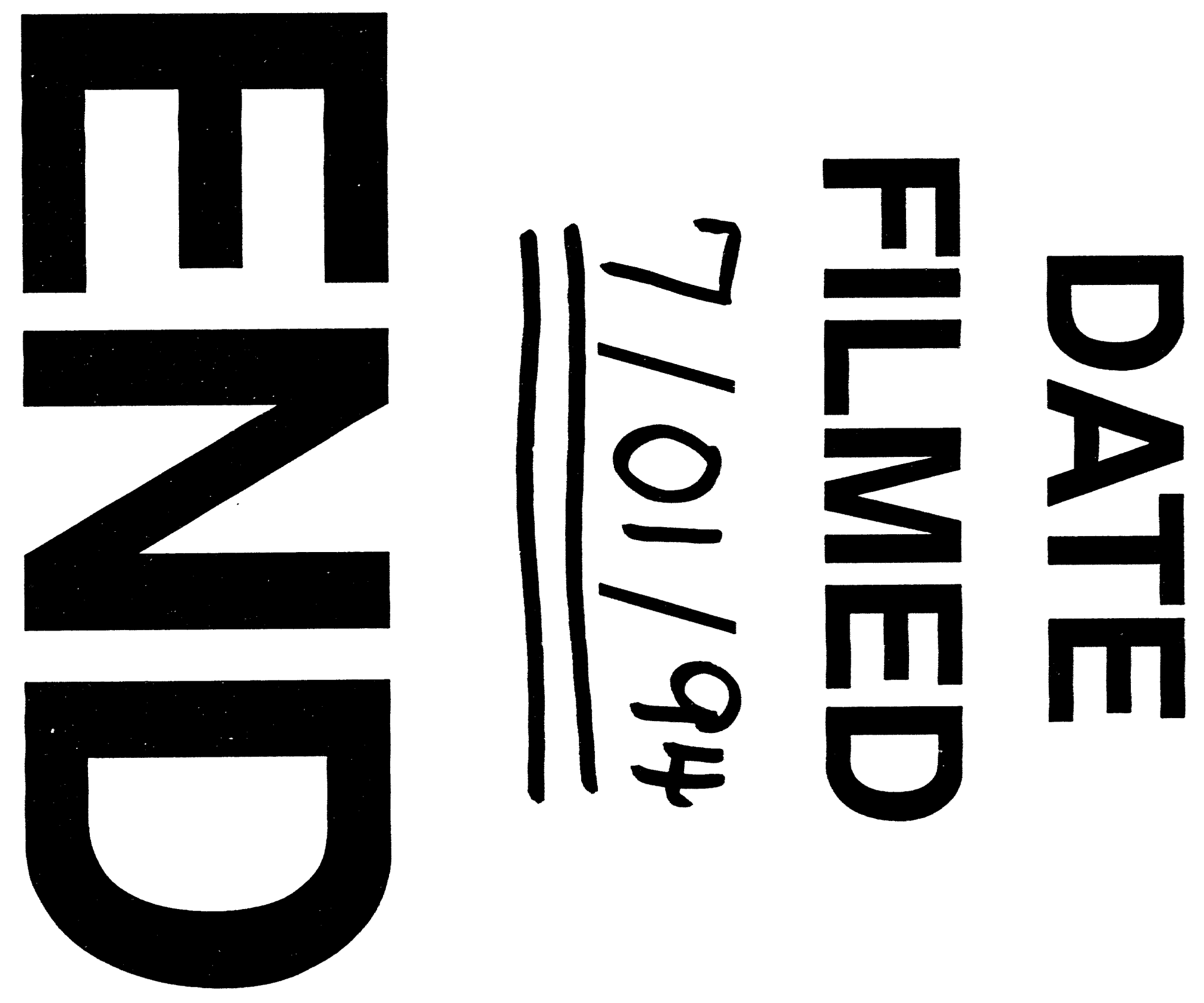


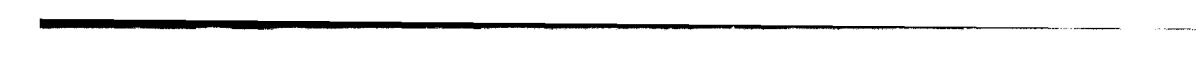

